\begin{tabular}{|c|l|}
\hline Title & The role of mouse 2,5 -oligoadenylate synthetase 1 paralogs \\
\hline Author(s) & Elkhateeb, Enas Hamed Mahmoud \\
\hline Citation & 北海道大学. 博士獣医学) 甲第12613号 \\
\hline Issue Date & 2017-03-23 \\
\hline DOI & 10.14943/doctoral.K12613 \\
\hline Doc URL & http://hdl.handle.net/2115/65640 \\
\hline Type & theses (doctoral) \\
\hline File Information & Enas_Hamed_Mahmoud_Elkhateeb.pdf \\
\hline
\end{tabular}

Instructions for use 
The role of mouse 2', 5'-oligoadenylate synthetase 1 paralogs

マウス 2’, 5’-オリゴアデニル酸合成酵素 1 パラログの役割

\section{Enas Elkhateeb}

Laboratory of Laboratory Animal Science and Medicine

Graduate School of Veterinary Medicine

Hokkaido University 


\section{Contents}

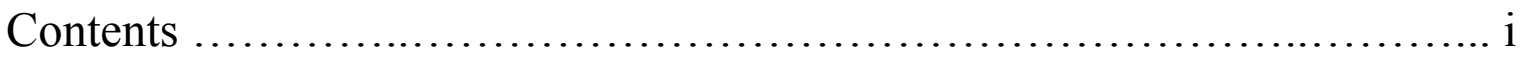

Abbreviations...........................................................

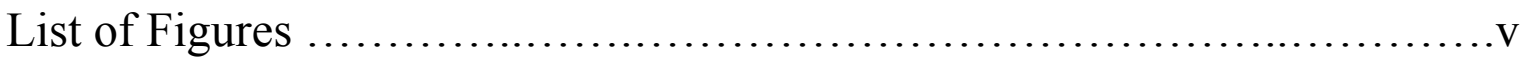

List of Table ................................................................ vii

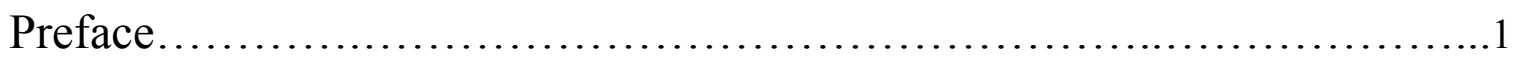

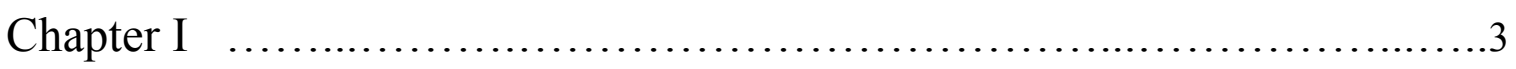

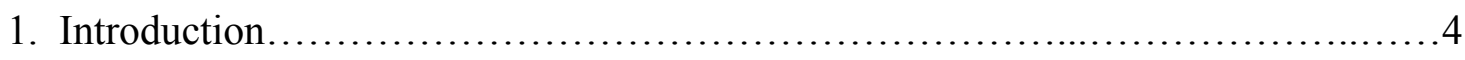

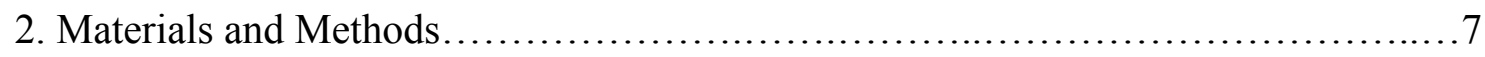

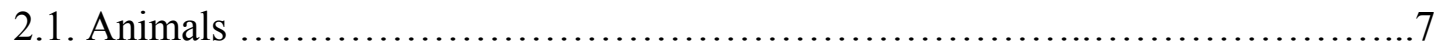

2.2 RNA extraction and reverse transcription-polymerase chain reaction (RT-PCR) ..7

2.3 Cloning and Flag-Tag conjunction............................................ 9

2.4 Assay of the OAS enzymatic activity ....................................... 10

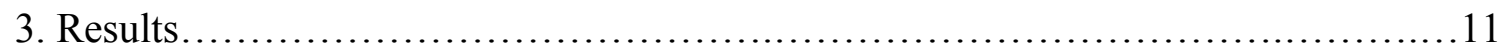

3.1 Expression profile of the mouse Oas 1 gene family ................................11

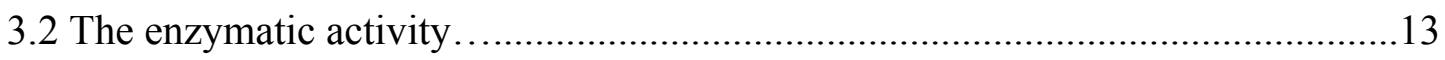

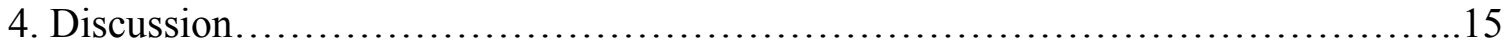

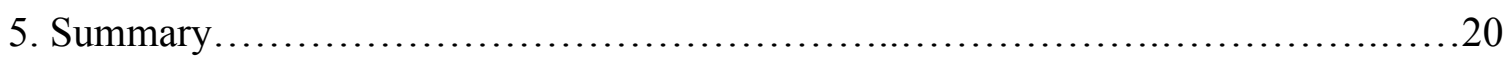


Chapter II........................................................... 21

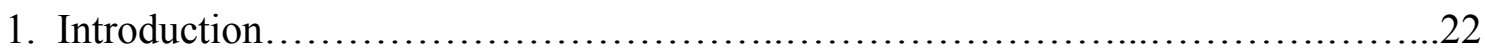

2. Materials and Methods............................................................ 25

2.1. Evaluation of the antiviral activity to WNV replicon........................25

2.2. Evaluation of antiviral activity to TBEV replicon.........................25

2.3. Statistical analysis.................................................26

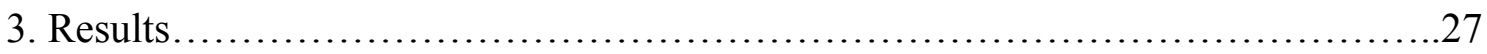

3.1 The antiviral activity of the mouse Oas1 family against WNV replicon.........27

3.2 The antiviral activity of the mouse Oas1 family against TBEV replicon.........30

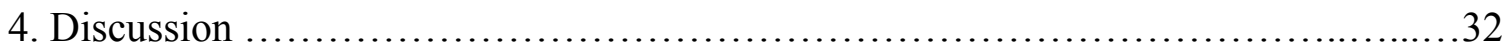

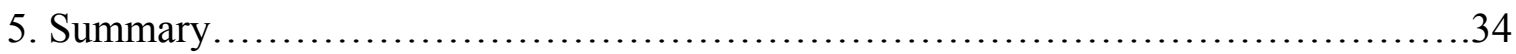

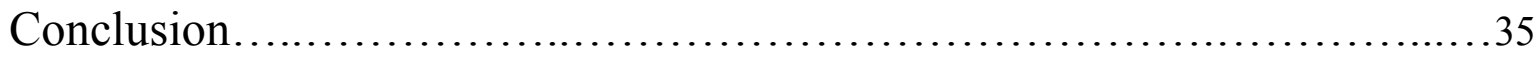

Acknowledgements.................................................. 36

References.......................................................... 37

Summary in Japanese..........................................42 


\section{Abbreviations}

\begin{tabular}{|c|c|}
\hline $2,5 \mathrm{~A}$ & 2', 5'-oligoadenylate \\
\hline Actb & actin, beta \\
\hline B6 & $\mathrm{C} 57 \mathrm{BL} / 6$ \\
\hline $\mathrm{bp}$ & base pair \\
\hline BSL & biosafety level \\
\hline $\mathrm{C}$ & capsid \\
\hline Chr & chromosome \\
\hline cDNA & complementary DNA \\
\hline CNS & central nervous system \\
\hline DMEM & Dulbecco's modified minimum essential medium \\
\hline dsRNA & double-stranded RNA \\
\hline $\mathrm{E}$ & envelope \\
\hline EGFP & enhanced GFP \\
\hline $\mathrm{EP}$ & electroporation \\
\hline $\mathrm{F}$ & forward primer \\
\hline GFP & green fluorescent protein \\
\hline IFN & interferon \\
\hline i.p. & intra-peritoneal \\
\hline ISG & interferon-stimulated gene \\
\hline NS & non-structural protein \\
\hline Oas & oligoadenylate synthetase \\
\hline $\mathrm{P} 2$ & physical containment level 2 \\
\hline PBS & phosphate-buffered saline \\
\hline prM & pre-membrane \\
\hline PCR & polymerase chain reaction \\
\hline
\end{tabular}


reverse primer

RT-PCR reverse transcription-PCR

SEAP secreted alkaline phosphatase

WNV West Nile virus

TBEV tick-borne encephalitis virus 


\section{List of Figures}

Figure 1. Oas/RNase L pathway.

Figure 2. OAS family in human and mouse.

Figure 3. (A) Gene expression pattern of the mouse Oas1 gene paralogs in male and female mouse tissues one week old. "(B)" Gene expression pattern of the mouse Oas1 gene paralogs in male and female mouse tissues five weeks old. "(C)" Gene expression pattern of the mouse Oas1 gene paralogs in male and female mouse tissues eight weeks old. "(D)" Gene expression pattern of the mouse Oas 1 gene paralogs in male and female mouse tissues five week old after intraperotenial injection of poly I.C. "(E)" Gene expression pattern of the mouse Oas1 gene paralogs in the Brain after intracranial injection of poly I.C.

Figure 4. (A) The enzymatic activity of the Oas1 family. (B) Western Blot analysis using anti- FLAG antibody.

Figure 5. (A) Alignment of amino acid sequence in mouse Oas1 paralogs. Amino acid sequence motifs important for the enzyme activity are shown in the box. Light gray rectangles, conserved OAS catalytic units; black rectangles, less conserved parts of the proteins. The multi-alignment was performed with the CLUSTALW program (www.ddbj.nig.ac.jp/E-mail/clustalw-j.html) using default parameters. The output was embellished using BOXSHADE 3.21 software (www.ch.embnet.org/software/ BOX_form.html). (B) Schematic diagram of mouse Oas1 protein and comparison of 5 motifs in mouse Oas1 paralogs.

Figure 6. Schematic figure of repWNV/SEAP replicon .The SEAP reporter gene (black box) fused with the FMDV 2A sequence (gray box) is inserted upstream of the nonstructural (NS) coding region instead of viral structural protein, core $(\mathrm{C})$, premembrane (prM) and envelope proteins (E). 
Figure 7. Schematic figure of the TBEV genome and replicon constructs. The gene for luciferase was inserted between the $\mathrm{C}$ and $\mathrm{E}$ protein-encoding regions of the TBEV genome. The foot and mouse disease virus (FMDV) 2A coding sequence (2A) was inserted between the C-terminus of luciferase gene and the NS1 signal sequence.

Figure 8. (A) Antiviral activity of the mouse Oas1 paralogs expressed in the BHK-21 cells against WNV replicon. (B) Confirmation of the expression level of the mouse Oas1 paralogs in the BHK-21 cells by RT-PCR before the electoporation of repWNV/SEAP replicon and after the antiviral assay. (C) Western blot analysis using anti-FLAG antibody.

Figure 9. Antiviral activity of the mouse Oas1 paralogs expressed in the BHK-21 cells against TBEV replicon. 


\section{List of Table}

Table 1. List of Oas1 family primers 


\section{Preface}

The interferon-induced oligoadenylate synthetase (OAS) family is one of the most important immune response proteins to the viral infection. The OAS protein binds dsRNA and is activated to produce 2', 5'-oligoadenylates, which lead to the activation of latent form of RNase L, resulting in degradation of cellular and viral RNA and inhibition of viral replication. The two features, which make the OAS enzymes unique, are the formation of 2', 5'-linked oliogonucleotides $(2,6)$ and the activation of the enzyme by dsRNA $(7,10)$. In mice, the Oas gene family locates on chromosome (Chr) 5. The mouse Oas gene locus undergoes a recent series of duplication event, leading to the presence of eight paralogs of Oas1 genes (Oas1a through Oas 1h) that forms Oas gene cluster with the Oas2, Oas3 and two OasL (OasL1 and OasL2) genes. Previous studies demonstrated that the mouse Oas $1 b$ gene conferred resistance to the flavivirus infection on mice; however, the antiviral activity of other mouse Oas 1 gene family is still unknown.

By comparing mouse Oas1 gene with human $O A S 1$ gene, the question arises as why the mouse possesses 8 paralogs of Oasl gene unlike the human and other mammals. To elucidate these questions, the author aimed in this study to make the characteristics of mouse Oas 1 paralogs clear with respect to the enzymatic activity and antiviral activity to flavivirus infection. Therefore, as concluded in Chapter I, the author has evaluated the mouse Oas1 paralogs regarding the enzymatic activity. The mouse Oas1 genes were cloned from C57BL/6J (B6) as well as the Oas1b derived

from feral mouse strain, MSM. The obtained results demonstrated that only OAS1a and OAS1g showed enzymatic activity.

West Nile virus (WNV) and tick-born encephalitis virus (TBEV) belong to genus Flavivirus, family of Flavivirdea and both viruses are arthropod born virus and both of them cause severe neurological diseases with extensive worldwide morbidity and mortality. In both viruses, the human is dead end host $(39,38,3)$. The incidence of TBEV is increasing in many endemic areas in the European countries, Russia and Far-Eastern Asia including Japan, about 10,000 cases of the disease 
are reported every year. In chapter II, the author has evaluated the antiviral activity against the two neurotropic flaviviruses, WNV and TBEV. Although MSM-derived Oas1b showed antiviral activity to both viruses, all B6-derived OAS paralogs did not show antiviral activity. These results suggest that OAS1a and OAS1g play a role in potentiating viral RNA-induced interferon response in the cell, whereas the Oas $1 \mathrm{~b}$ works as a specific anti-flavivirus factor unless it is mutated. However, the role of other paralogs is unknown and should wait for further investigation.

The contents of this research are published in the following article.

Elkhateeb, E., Tag-El-Din-Hassan, H.T., Sasaki, N., Torigoe, D., Morimatsu, M., and Agui, T. 2016. The role of mouse 2', 5'-oligoadenylate synthetase 1 paralogs. Infect. Genet. Evol. 45: 393-401 


\section{Chapter I}

Expression, Cloning, and Enzymatic Activities of Oas1 Paralogs 


\section{Introduction}

The antiviral activity of interferon (IFN)-induced proteins such as double-stranded RNA (dsRNA)-activated protein kinase (PKR), 2', 5'-oligoadenylate synthetase (OAS), and MX protein GTPase play a critical role in host immune response $(32,2)$. The OAS proteins are highly induced by type 1 IFN and to lesser extent by type 2 IFN. The two features, which make the OAS enzymes unique, are the formation of 2', 5'-linked oliogonucleotides $(2,6)$ and the activation of the enzyme by dsRNA $(7,10)$. When the OAS protein is activated upon interaction with viral dsRNA, it polymerizes ATP into 2, 5A, which in turn binds and activates the latent RNase L. The activated RNase L degrades both cellular and viral RNA, leading to the inhibition of cellular and viral protein synthesis as shown in (Figure. 1). The OAS/RNase L pathway enables the host cell to restrict viral propagation $(33,18)$. Furthermore, the $\mathrm{OAS} / \mathrm{RNase} \mathrm{L}$ pathway activates pattern recognition receptors such as RIG-I and MDA5, leading to increase in the production of IFN type 1 (19). Previous study demonstrated that the action of IFN $\alpha / B$ was impaired in $\mathrm{RNase}^{-\digamma}$ mice (43). In addition to its antiviral role, the OAS/RNase L pathway is also involved in some biological functions such as cell differentiation, division, and apoptosis $(43,1)$. Moreover, this pathway plays a role in heat shock, diabetes type 1, and prostate cancer (16).

OASs are ancient protein families with multiple antiviral activities (12). The range of their intracellular concentration is widely increased depending on the functional specificity of a cell, the phase of the cell cycle. Intracellular concentration of oligoadenylates also changes in the case of viral infection. The normal 2, 5A intracellular concentration is below $1 \mathrm{nM}$. It can increase several times and reach $10 \mathrm{nM}$ in the case of OAS induction by IFN (36). 


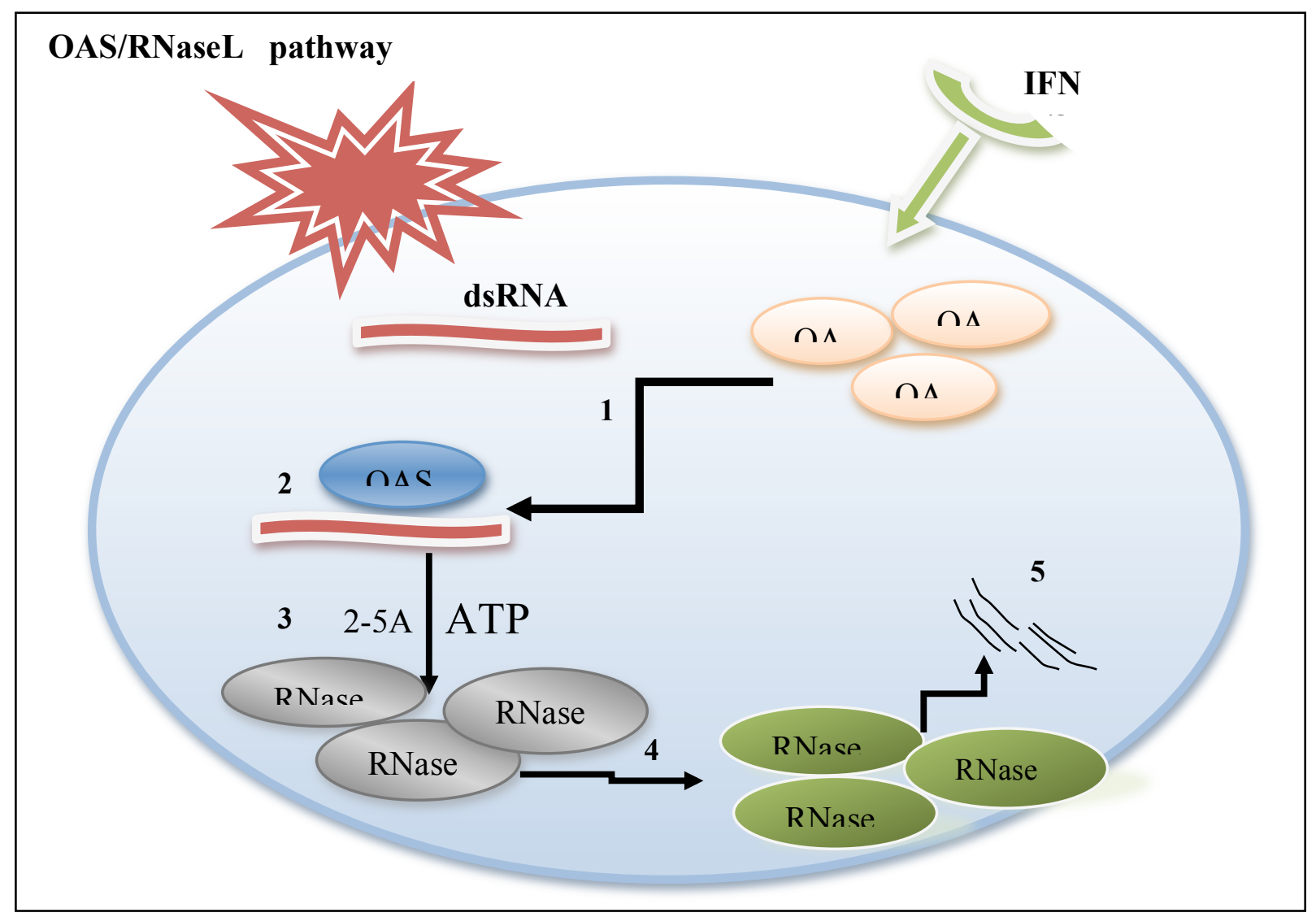

Figure 1. Oas/RNase L pathway. Oas/RNase L pathway is well known antiviral machinery in innate state. 1, Oas genes are induced by type 1 IFN. 2, Oas proteins bind virus-derived dsRNA and are activated. 3, Activated Oas synthesizes 2, 5A. 4, 2, 5A activates latent RNase L. 5, Activated RNase L causes viral RNA degradation.

In humans, the OAS gene family consists of four classes of genes, OAS1 (p40/p46, short form), OAS2 (p69/p71, middle form), OAS3 (p100, long form), and OASL (p59, or OAS-like) located on chromosome (Chr) $12(11,27,31)$. However, in mice, the $O A S$ gene family locates on Chr 5 and consists of eight genes of Oas1 (Oas1a through Oas1h), Oas2, Oas3, and two OasL genes (OasL1 and OasL2) $(3,13,20)$ as shown in (Figure. 2). Mouse Oas2 and Oas3 have a genomic structure similar to that of human Oas2 and Oas3, while the mouse Oas1 is equivalent to the human Oas1, although it is composed of eight genes (Oas1a to Oas1h). It has been shown that mouse Oas $1 b$ provides resistance to flavivirus infection $(26,19)$; however, mouse Oas $1 \mathrm{~b}$ is enzymatically inactive and independent of RNase L (5). The mechanism of antiviral activity of Oas $1 b$ is still unclear. 


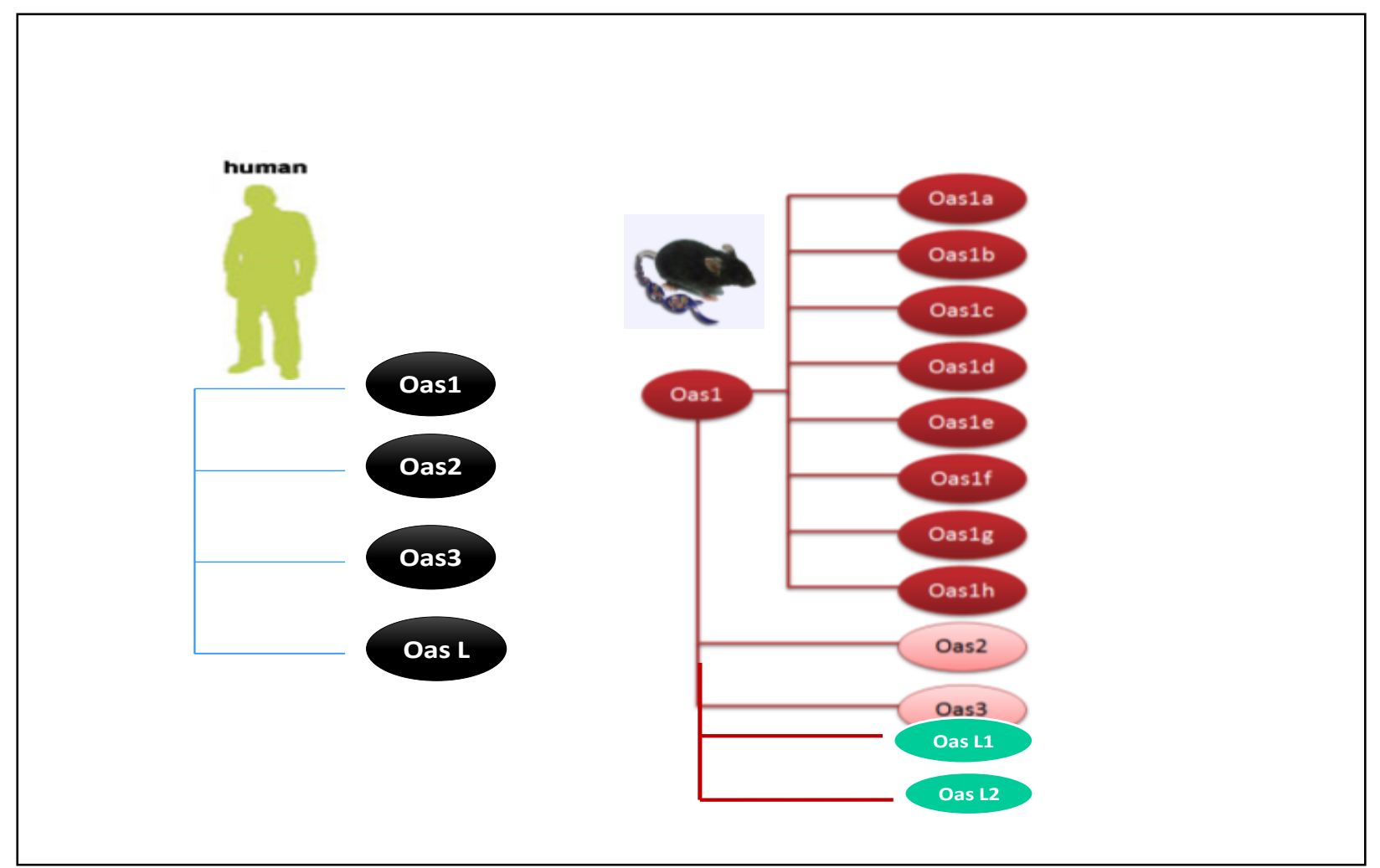

Figure 2. OAS family in human and mouse

By comparing mouse Oas 1 gene with human $O A S 1$ gene, the question arises as why the mouse possesses 8 paralogs of Oas1 gene unlike the human and other mammals and what the roles of these paralogs are. To elucidate these questions, the author aimed in Chapter I to make the characteristics of mouse Oas1 paralogs clear with respect to the expression in various tissues and the enzymatic activity. 


\section{Materials and Methods}

\subsection{Animals}

Male and female $\mathrm{C} 57 \mathrm{BL} / 6 \mathrm{~J}$ mice at 1,5 , and 8 weeks of age were sacrificed by cervical dislocation and spleen, liver, lung, kidney, testes, ovary, and skin were dissected. Five-week-old male and female mice were also received intra-peritoneal (i.p.) administration of $250 \mu 1$ phosphatebuffered saline (PBS) containing $400 \mu \mathrm{g}$ poly I:C (Sigma, St. Louis, MO, USA). Mice were sacrificed by cervical dislocation at $12 \mathrm{hr}$ after the poly I:C administration, then, spleen, liver, lung, kidney, testes, ovary, and skin were dissected. To induce the mouse Oas 1 gene family in the brain, three B6 male mice at 5 weeks old were intra-cranially injected as follows; no injection (sham control), $20 \mu \mathrm{l}$ PBS (control), and $40 \mu \mathrm{g}$ poly I:C in $20 \mu \mathrm{l}$ PBS. Mice were sacrificed by excessive dose of isoflurane at $24 \mathrm{hr}$ after injection, and then, whole brains were dissected. The animal use protocol was approved by the President of Hokkaido University after reviewing by the Institutional Animal Care and Use Committee of Hokkaido University.

\subsection{RNA extraction and reverse transcription-polymerase chain reaction (RT-PCR)}

Total RNAs were extracted from dissected organs using TRIzol ${ }^{\circledR}$ reagent (Invitrogen, Carlsbad, CA, USA), and kept at $-80{ }^{\circ} \mathrm{C}$ until used. Complementary DNAs (cDNAs) were generated with oligo(dT) primer using ReverTra Ace ${ }^{\circledR}$ (TOYOBO, Osaka, Japan) according to the manufacturer's protocol. The synthesized cDNAs were used for the PCR to amplify mouse Oas 1 gene paralogs, Oas1a, Oas1b, Oaslc, Oas1d, Oasle, Oaslf, Oas1g, and Oas1h, using specific primers (Table 1). The PCR conditions were as follows; initial denaturation at $95^{\circ} \mathrm{C}$ for $5 \mathrm{~min}, 35$ cycles of denaturation at $95{ }^{\circ} \mathrm{C}$ for $30 \mathrm{sec}$, annealing at $60{ }^{\circ} \mathrm{C}$ for $30 \mathrm{sec}$, and extension at $72{ }^{\circ} \mathrm{C}$ for $1.5 \mathrm{~min}$ followed by the final extension at $72{ }^{\circ} \mathrm{C}$ for $3 \mathrm{~min}$. PCR products were electrophoresed in $1 \%$ agarose gels and visualized by ethidium bromide staining. 
Table 1. List of Oas1 family primers.

\begin{tabular}{|c|c|c|c|c|}
\hline$\overline{O A S \text { gene }}$ & Primers & ORF & $\mathrm{Tm}$ & Amino acid \\
\hline \multirow[t]{2}{*}{ Oasla } & F/ CTTAGCATGGAGCACGGACTCAGG & 1134 & 60 & 367 \\
\hline & R/ ATCAGAAGCACGGAGTCTGATGCC & & & \\
\hline \multirow[t]{2}{*}{ Oas $1 b$} & F/ TAAAAGCTGGACCTAGGATGGAGC & 1139 & 60 & 376 \\
\hline & R/ CATAACAGGCCTACGCTGCAGTC & & & \\
\hline \multirow[t]{2}{*}{ Oaslc } & F/ TCAGGATGGAGAATGGTCTCTGCA & 1094 & 58 & 362 \\
\hline & R/ TCA CTG GAA GGC ACA TTC TTG TCT CTC & & & \\
\hline \multirow[t]{2}{*}{ Oasld } & F/ ATGGCGAGGGAACTCTTCAGAACC & 1089 & 60 & 361 \\
\hline & R/ T CA C AG G AA G AC A CA T TC TTGT & & & \\
\hline \multirow[t]{2}{*}{ Oasle } & F/ ATGGCGAGGGAACTCTTCATAACC & 1077 & 58 & 356 \\
\hline & R/ TTA TTG TTT CTC TGG CGA CAC TTC & & & \\
\hline \multirow[t]{2}{*}{ Oaslf } & F/ ATGGTGAAGGATCTTAGCAGCACC & 1108 & 60 & 366 \\
\hline & R/ TCA TAG AAG GAC ACA GTC CTG & & & \\
\hline \multirow[t]{2}{*}{ Oas $1 g$} & F/ ATGGAGCACGGACTCAGGAGCAT & 1114 & 60 & 366 \\
\hline & R/ TCA CAG CAG GAT ACA TGT CCA GTTC & & & \\
\hline \multirow[t]{2}{*}{ Oas $1 \mathrm{~h}$} & F/ ATGGCGAAAAACCTTAGCAGCACT & 1115 & 50 & 369 \\
\hline & R/ TCA CAG GAA GAC AAA TCC TTT TTT & & & \\
\hline \multirow[t]{2}{*}{$\beta$-actin } & F/ CATCGTGGGCCGCTCTAGGC & 980 & 64.2 & \\
\hline & R/ GCTTGCTGATCCACATCTGC & & & \\
\hline
\end{tabular}




\subsection{Cloning and Flag-Tag conjunction}

The PCR products of the mouse Oas 1 gene paralogs were extracted from agarose gel by the Fast Gene Gel/PCR Extraction Kit (Nippon Genetics Co., Ltd, Tokyo, Japan), and the extracted products were cloned into pGEM-T Easy vector (Promega, Madison, WI, USA) in the transformed E. coli, DH5a, and then extracted by the FastGene Plasmid Mini Kit (Nippon Genetics Co., Ltd). Three different clones form each gene were sequenced to confirm no errors. The sequence coding for the FLAG-TAG (FL) peptide DYKDDDDK was added to the reverse primers for mouse Oas1a, Oas $1 b$, and Oaslc and to forward primers for Oas1d, Oasle, Oas1f, Oas1g, and Oas1h (Table 1), and PCR was performed. The PCR conditions were as follows; initial denaturation at $95^{\circ} \mathrm{C}$ for 5 min, 10 cycles of denaturation at $95{ }^{\circ} \mathrm{C}$ for $30 \mathrm{sec}$, annealing at $60{ }^{\circ} \mathrm{C}$ for $30 \mathrm{sec}$, and extension at $72{ }^{\circ} \mathrm{C}$ for 1.5 min followed by final extension at $72{ }^{\circ} \mathrm{C}$ for $3 \mathrm{~min}$ and digestion by different restriction enzymes. The PCR products were cloned into pGEM-T Easy vectors (Promega). Three different clones from each gene were sequenced to confirm no errors, and inserted genes were cut with EcoRI restriction enzyme and inserted into the mammalian expression vector, pIRES-EGFP vector (Clontech Laboratories, Inc., Shiga, Japan) to generate pB6.Oas1a-FL-EGFP, pB6.Oas 1b-FL-EGFP, pB6.Oas1c-FL-EGFP, pB6.Oas1d-FL-EGFP, pB6.Oas1e-FL-EGFP, pB6.Oas1f-FL-EGFP, pB6.Oas1g-FL-EGFP, pB6.Oas1h-FL-EGFP, as well as pMSM.Oas1b-FL-EGFP. Large-scaled culture was performed in the transformed E. coli, DH5a, and then plasmids were purified by $\mathrm{CsCl}_{2}$-ethidium bromide gradient purification method.

Cloning of mouse Oas1 paralogs in pIRES-GFP vector was confirmed by PCR with specific primers for Oas1 paralog genes and vector shown in Table 1. The PCR conditions were as follows; initial denaturation at $95^{\circ} \mathrm{C}$ for $5 \mathrm{~min}, 10$ cycles of denaturation at $95^{\circ} \mathrm{C}$ for $30 \mathrm{sec}$, annealing at 60 ${ }^{\circ} \mathrm{C}$ for $30 \mathrm{sec}$, and extension at $72{ }^{\circ} \mathrm{C}$ for $1.5 \mathrm{~min}$ followed by final extension at $72{ }^{\circ} \mathrm{C}$ for $3 \mathrm{~min}$. PCR products were electrophoresed in 1\% agarose gels and visualized by ethidium bromide staining. 


\subsection{Assay of the OAS enzymatic activity}

The measurement of enzymatic activity was performed as previously described (30). In brief, HEK293FT cells were grown in Dulbecco's modified minimum essential medium (DMEM) (Gibco/Invitrogen, Carlsbad, CA, USA) supplemented with 10\% fetal bovine serum and $1 \%$ penicillin/streptomycin/Glutamine (Gibco/Invitrogen) at $37^{\circ} \mathrm{C}$, and passaged every two days. The cells were cultured in DMEM at the cell density of $1 \times 10^{6}$ cells in a 60-mm dish for $24 \mathrm{hr}$ and transfected with $5 \mu \mathrm{g}$ of each plasmid, pB6.Oas1a-FL-EGFP, pB6.Oas1b-FL-EGFP, pB6.Oas1cFL-EGFP, pB6.Oas1d-FL-EGFP, pB6.Oas1e-FL-EGFP, pB6.Oas1f-FL-EGFP, pB6.Oas1g-FLEGFP, pB6.Oas1h-FL-EGFP as well as pMSM.Oas1b-FL-EGFP. After $72 \mathrm{hr}$, each cell fraction was homogenized in $500 \mu \mathrm{l}$ of ice-cold $300 \mathrm{mM} \mathrm{NaCl}, 20 \mathrm{mM}$ Tris- $\mathrm{HCl}(\mathrm{pH}$ 7.5), 10\% glycerol, $0.2 \%$ Triton X-100, $5 \mathrm{mM}$ 8-mercaptoethanol, and $1 \mathrm{x}$ protease inhibitors (2 $\mathrm{mg} / \mathrm{ml}$ aprotinin, $1 \mathrm{mg} / \mathrm{ml}$ pepstatin $\mathrm{A}$, and $2 \mathrm{mg} / \mathrm{ml}$ leupeptin). Western blot analysis was performed using a monoclonal anti-FLAG M2 antibody (Sigma-Aldrich, St. Louis, MO, USA) using ECL Advance Western Blotting Detection Kit (GE Healthcare UK Limited, Little Chalfont, UK) according to the manufacturer's instructions. The bands were detected with a Luminescence Image Analyzer LAS 3000 (Fujifilm, Tokyo, Japan). An aliquot of the $2.5 \mu \mathrm{l}$ of whole cell lysates was incubated in the reaction buffer [20 mM Tris- $\mathrm{HCl}$ (pH 7.4), $20 \mathrm{mM}$ magnesium acetate, $2.5 \mathrm{mM}$ dithiothreitol, $5 \mathrm{mM} \mathrm{ATP,} 50$ $\mu \mathrm{g} / \mathrm{ml}$ poly I:C, and $5 \mu \mathrm{Ci}$ of $\left.\left[\alpha^{-32} \mathrm{P}\right] \operatorname{ATP}(3,000 \mathrm{Ci} / \mathrm{mmol})\right]$ in a final volume of $10 \mu \mathrm{l}$ for $18 \mathrm{hr}$ at $30{ }^{\circ} \mathrm{C}$. The synthesized $2,5 \mathrm{~A}$ products were separated on a $20 \%$ polyacrylamide-urea (7M) gel, and visualized by the autoradiography with a BAS-2500 Bio-Imaging Analyzer (Fujifilm). 


\section{Results}

\subsection{Expression profile of the mouse Oas1 gene family}

Figure 3 shows the expression profile of the mouse Oas 1 gene paralogs in different tissues from B6 mice of three different ages, new born (A) (1 week old), (B) young (5 weeks old), and adult (C) (8 weeks old) and 5-week-old mice stimulated with poly I:C. The expression of Oas 1a, Oas 1b, and Oaslg was much increased by the stimulation of poly I:C in all tissues, suggesting that these paralogs were expressed mainly in a virus- or IFN-stimulated manner. On the other hand, the expression of other paralogs was restricted to the specific tissues and relatively independent of the poly I:C stimulation. Thus, the Oas 1 , Oas $1 d$, and Oasle, were expressed in ovary, and the Oas $1 f$ was expressed in skin in the steady state conditions. These results suggest that the Oas $1 a$, Oas 1 , and Oas $1 g$ genes play a general role in various tissues in the stimulation of virus or IFN, whereas others work as somewhat specific factors in the respective tissues. In the brain, only Oas1a, Oas1b, and Oas1g were expressed in the mice stimulated with poly I:C (Figure $3(\mathrm{E})$ ). 
(A)
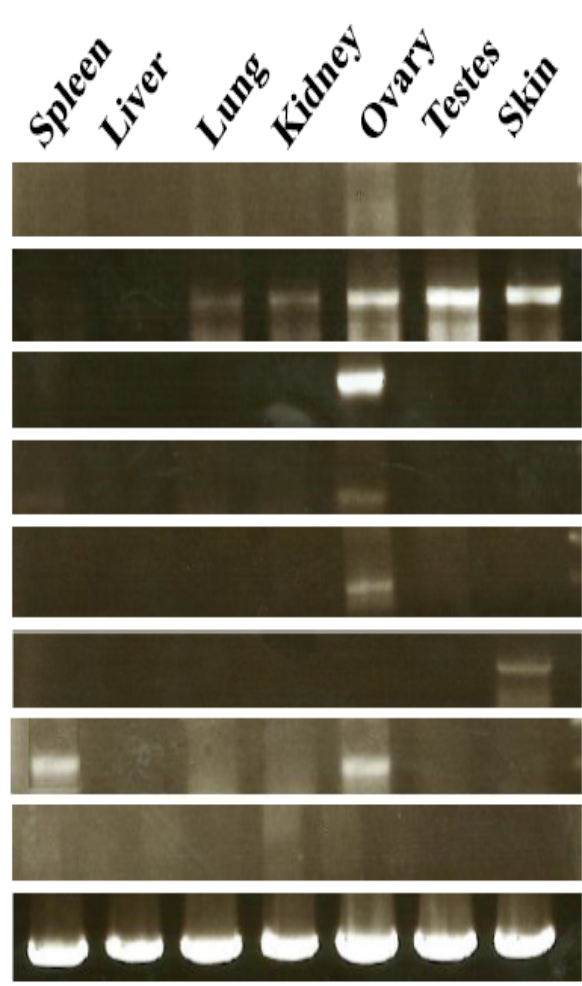

(C)
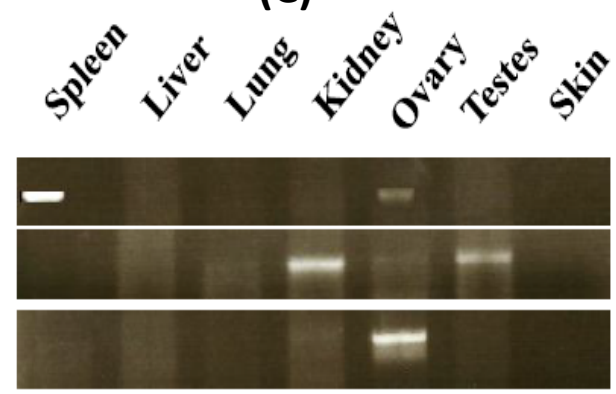

Oas1a

Oas1b

Oas1c

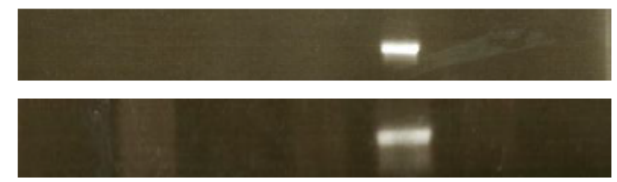

Oas1d

Oasle

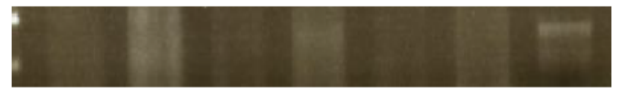

Oas1f

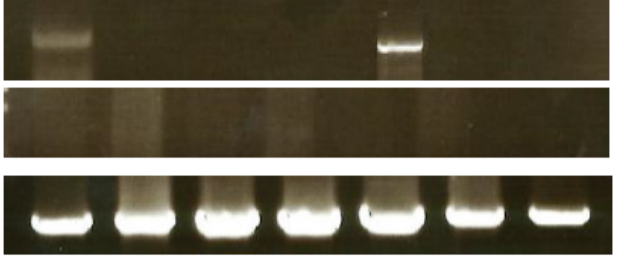

(B)
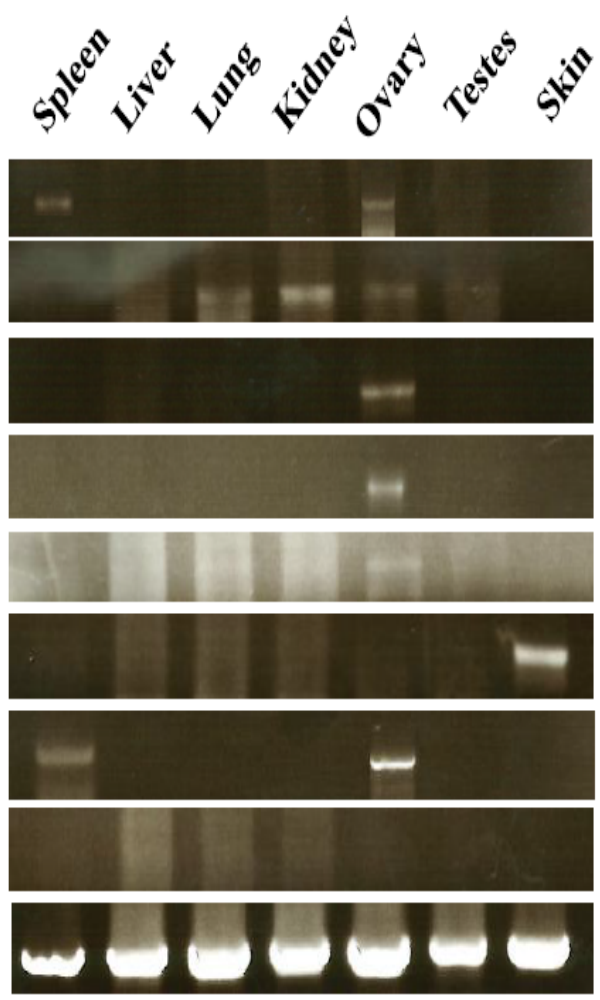

Oas1a

Oas1b

Oaslc

Oasld

Oasle

OasIf

Oaslg

Oas1h

Actb

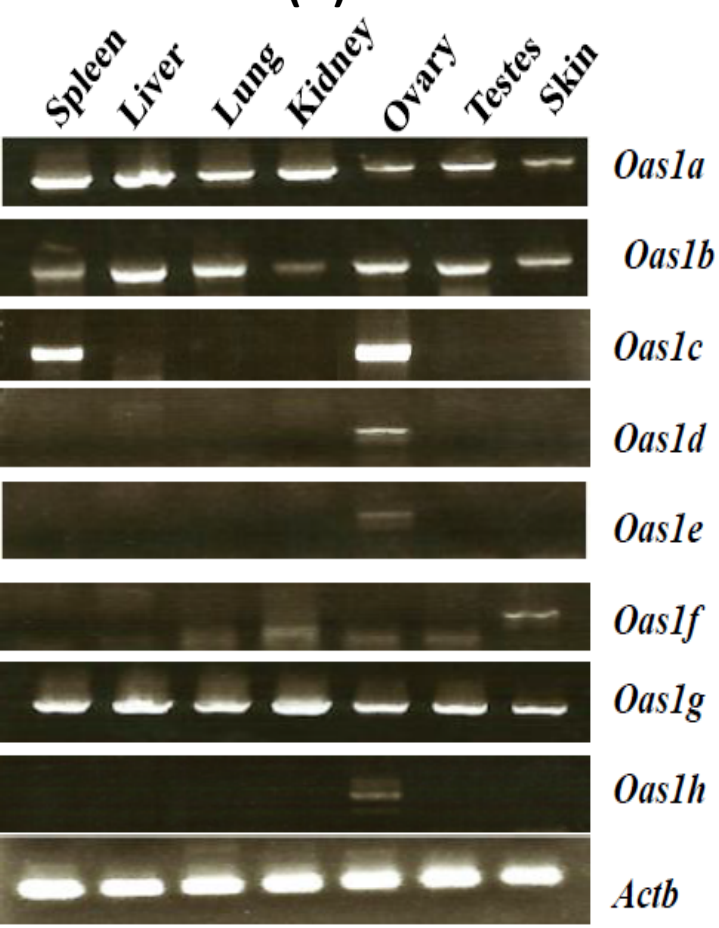


(E)

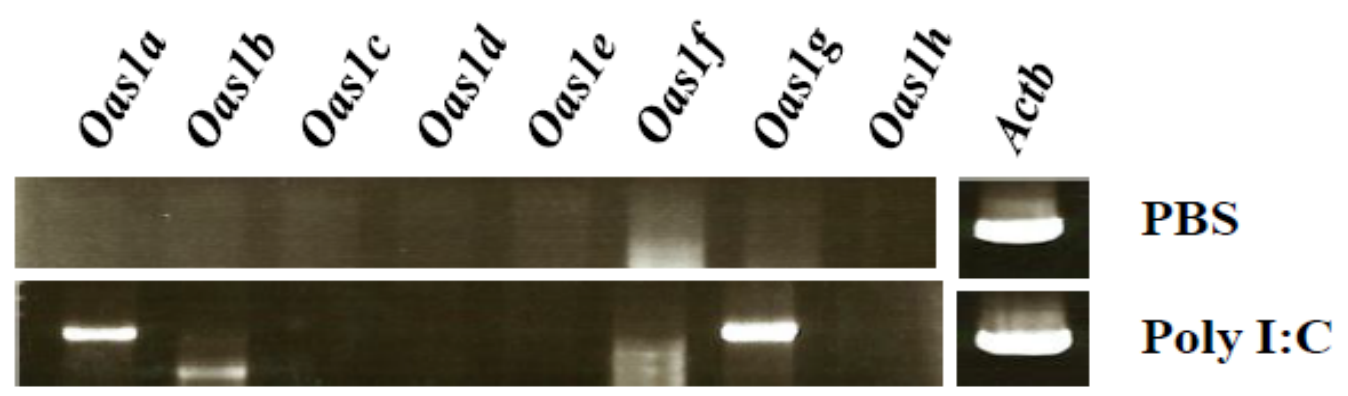

Figure 3. Gene expression pattern of the mouse Oas 1 paralogs in mice. Male and female mice at 1, 5, and 8 weeks old were sacrificed, RNAs were extracted from various tissues, and RT-PCR was performed. (A) 1 week old (B) 5 weeks old, (C) 8 weeks old. (D) Male and female mice at 5 weeks old were sacrificed at $12 \mathrm{hr}$ after intra-peritoneal injection of poly I:C, RNAs were extracted from various tissues, and RT-PCR was performed. Tissues from 1-week-old mice were combined from 3 to 4 mice. Tissues from other ages were individually collected from 2 mice and data are representative of the two mice. (E) Two male mice were received intra-cranial injection of poly I:C, sacrificed at $12 \mathrm{hr}$ after injection, RNA was extracted from the whole brain, and RT-PCR was performed. Data are representative of two mice.

\subsection{The enzymatic activity}

The enzymatic activity of the B6-derived Oas1 paralogs was evaluated in the HEK293FT cell after transfection. The result showed that Oas1a and Oas1g were only active to convert ATP into diand tri-2, 5A, whereas Oas1b, Oas1c, Oas1d, Oas1e, Oas1f, Oas1h, and MSM-derived Oas1b as well as the empty vector were inactive (Figure 4 (A)). Western blot analysis confirmed that the difference in the enzymatic activity was not due to the difference in the expression level of the transfected paralog proteins at the enzymatic assay (Figure 4 (B)). 

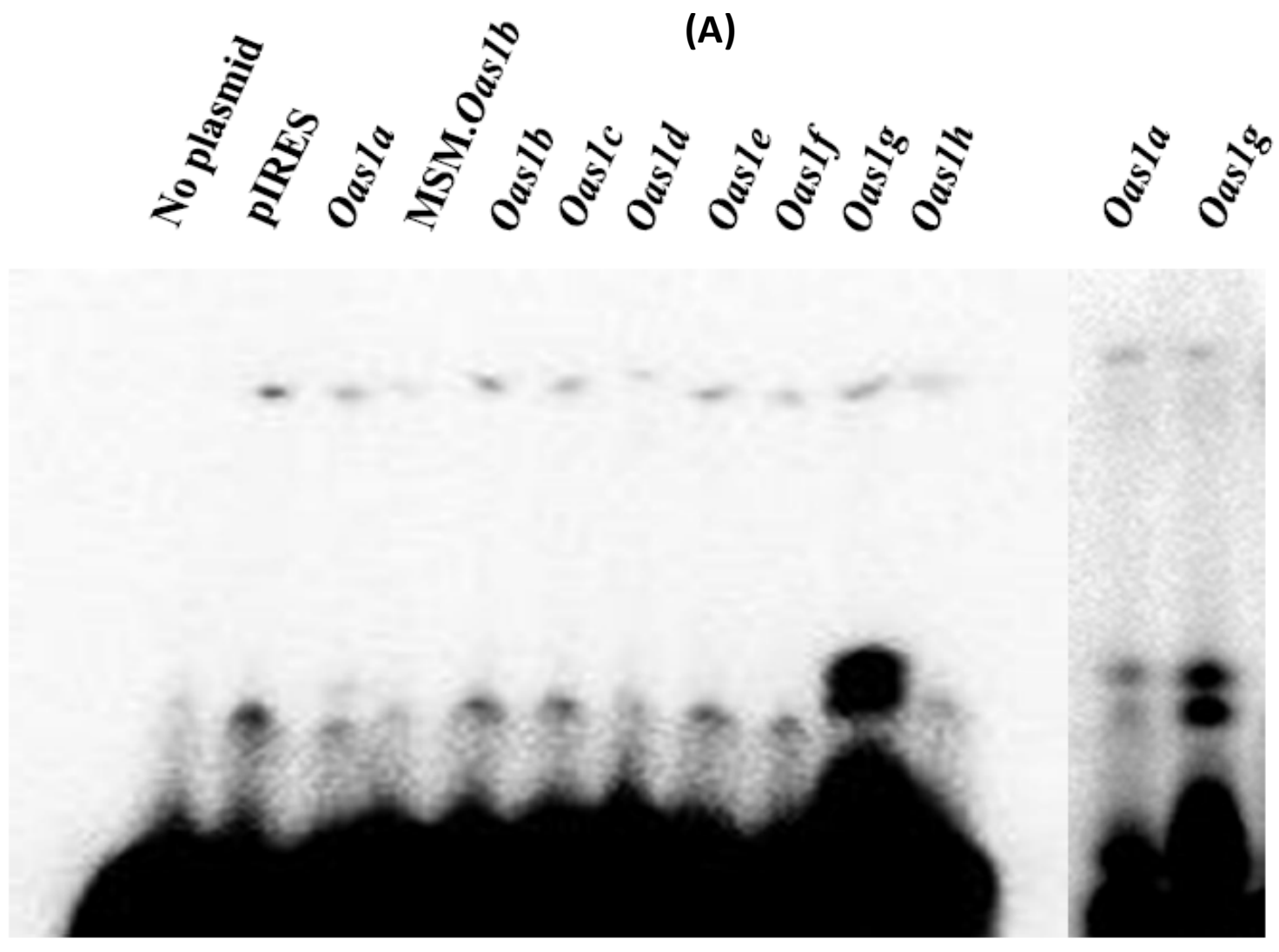

(B)
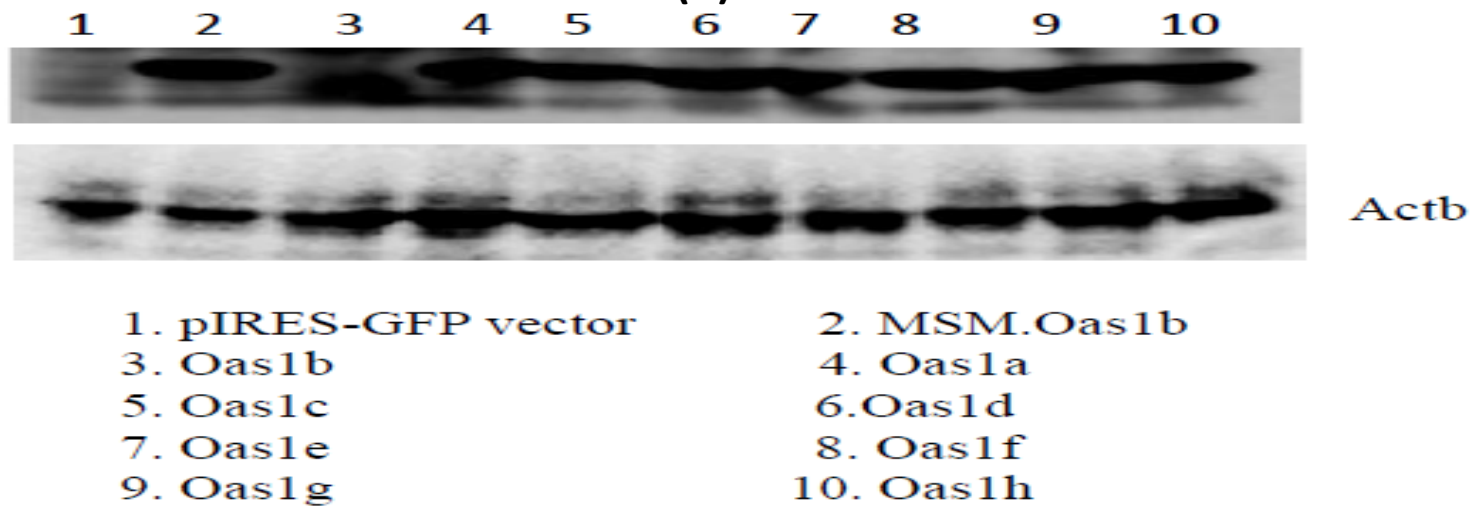

Figure 4. The enzymatic activity of the Oas1 family. (A) Homogenates of HEK293FT cells $\left(1 \times 10^{6}\right)$ transfected with pIRES-EGFP (control), pB6.Oas1a-FL-EGFP, pB6.Oas1b-FL-EGFP, pB6.Oas1c-FL-EGFP, pB6.Oas1d-FL-EGFP, pB6.Oas1e-FL-EGFP, pB6.Oas1f-FL-EGFP, pB6.Oas1g-FL-EGFP, pB6.Oas1h-FL-EGFP as well as pMSM.Oas1bFL-EGFP were subjected to the OAS enzymatic assay. The Oas1a and Oas1g showed enzymatic activity, whereas Oas1b, Oas1c, Oas1d, Oas1e, Oas1f, Oas1h and MSM-derived Oas1b had no enzymatic activity. (B) Samples in A were subjected to Western blot analysis using anti-FLAG antibody to assure retaining of the proteins of transfected genes. All paralog proteins were retained in the cell with the similar extent. 


\section{Discussion}

The OAS induced by IFN is widely distributed not only in mammalian cells but also in marine sponge $(30,15)$. The OAS plays a critical role in innate immunity. At the viral infection, dsRNA activates the OAS to convert ATP into 2, 5A and leads to the activation of the latent RNase L. The activated RNase L degrades both cellular and viral RNAs at the position after UU and UA dinucleotides, which leads to the inhibition of the viral replication and apoptosis of the cell. The product of RNA cleavage contributes to further activation of IFN. In this study, the author found that each paralog of mouse Oas1 gene family had a distinct RNA expression pattern; the Oasla, Oas 1 , and Oas $1 g$ are expressed ubiquitously in all organs and their expression is augmented upon stimulation by poly I:C. On the other hand, the Oas $1 f$ was expressed in skin only, and the Oas $1 c$, Oasld, and Oasle were expressed in ovary only. Furthermore, these expressions of the Oas 1 paralog genes were relatively independent of the poly I:C stimulation. These results are partially consistent with the previous study (13). The difference may be attributed in part to the detection method, RT-PCR vs Northern blotting. Expression profile of mouse Oas 1 paralog genes except for Oas $1 a$, Oas 1b, and Oas $1 g$ in this study suggests that these genes have tissue-specific and different functions. For example, it has been reported that Oas1d plays a role in ovulation and knocking out this gene reduces the fertility (39). However, the functions of other Oas 1 gene paralogs are still unclear.

To identify the role of Oas1 family, the author evaluated the enzymatic and antiviral activities of each paralog. First, the evaluation of the enzymatic activity of Oas1 paralogs including MSMderived Oas1b was performed. The results indicated that both Oas1a and Oas1g had enzymatic activity, whereas the B6-derived Oas1b, a truncated protein, Oas1c, Oas1d, Oas1e, Oas1f, Oas1h, and MSM-derived Oas1b had no enzymatic activity as well as empty vector. In order to clarify the reason for the lack of enzymatic activity in other paralogs than Oas1a and Oas1g, the author made a sequence alignment of Oas1 paralogs (Figure 5 (A)). The mouse Oas1 protein consists of five 
domains. The N-terminal domain contains LxxxP motif shown to be required for enzymatic activity in the previous report (6), P-loop motif which is an ATP binding site (35), DAD motif in D box which is $\mathrm{Mg}^{2+}$ binding site (40), $\mathrm{K}-\mathrm{R}$ rich region which is oligoadenylate and ATP binding site (22), and CFK motif located in the C-terminal domain which is required for tetramerization of the proteins (6). All of them are considered to be important for the enzymatic activity. Multi-alignment of the amino acid sequence of mouse Oas1 paralogs (Figure 5 (A)) and the comparison of each motif (Figure 5 (B)) demonstrate that mouse Oas1a and Oas1g possess the OAS enzymatic activity, since all motifs are conserved. Oas1a and Oas1g contain substitution of CFK motif, K to I; however, it is not likely to affect the structural stability of tetramerization of the proteins. Oas1b, Oas1c, Oas1d, Oas1e, Oas1f, Oas1h, and MSM.Oas1b do not possess the OAS enzymatic activity. Lack of enzymatic activity may be attributed to facts that LxxxP, P-loop, D Box, and K-R rich region are not conserved in these proteins. Although CFK motif is conserved in Oas1h, it is not enough to possess the enzymatic activity. The B6.Oas1b and MSM.Oas1b possess a 4 amino acid deletion in the P-loop, which may prevent it from folding into a catalytically functional structure, and substitution in $\mathrm{K}-\mathrm{R}$ rich region, $\mathrm{K}$ to $\mathrm{N}$, may cause the difficulty in substrate binding. These substitutions predict that MSM.Oas1b does not possess enzymatic activity. Previous study by using site-directed mutagenesis supports our interpretation, which demonstrated that the mutation in Ploop, K-R rich region, and D box exhibited a reduced enzymatic activities compared with the wildtype enzyme (40). 
(A)

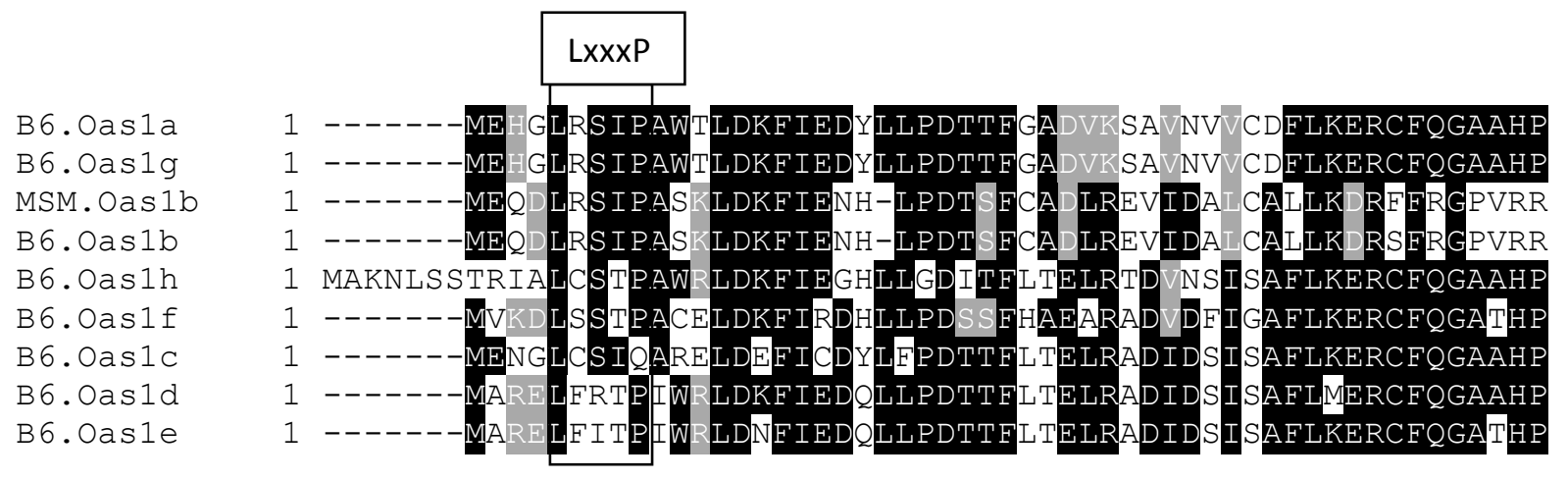

B6. Oasla

B6. Oaslg

MSM. Oas1b

B6.0as1b

B6.Oas1h

B6.0aslf

B6. Oas1C

B6. Oas1d

B6. Oasle

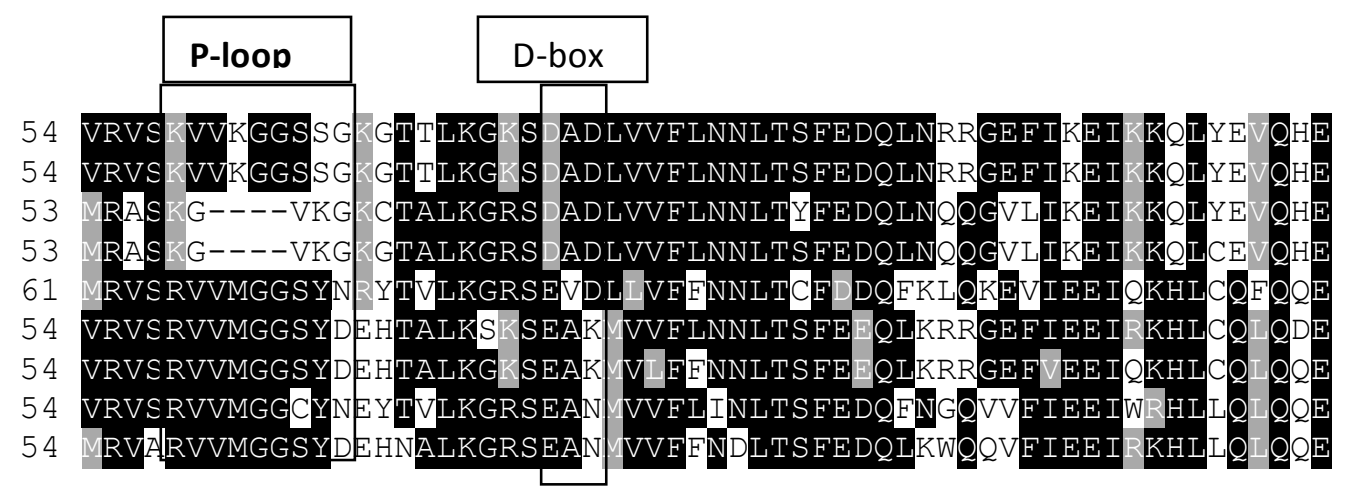

B6. Oasla
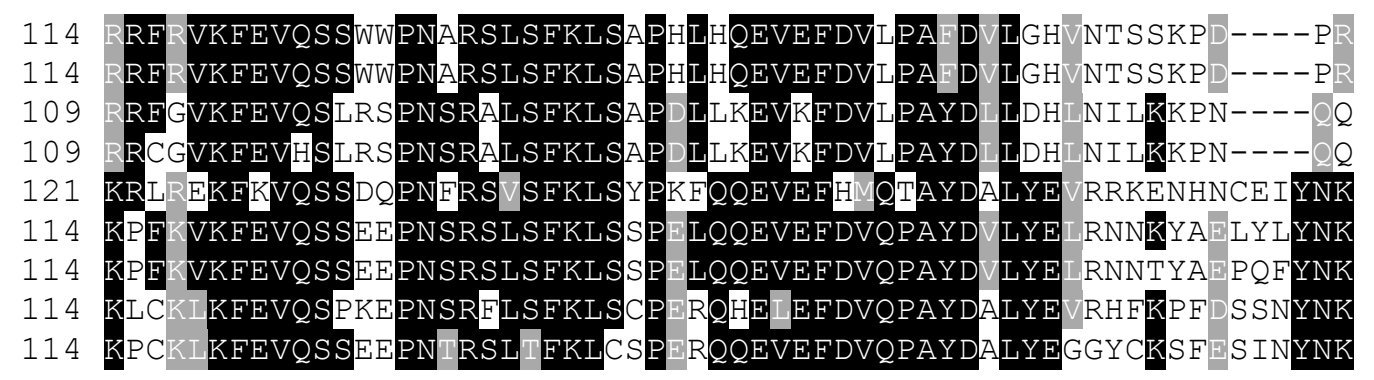

B6. Oaslg

MSM. Oas 1b

B6. Oas1b

B6.Oas1h

B6.Oas1f

B6. Oas1C

B6. Oas1d

B6.Oasle

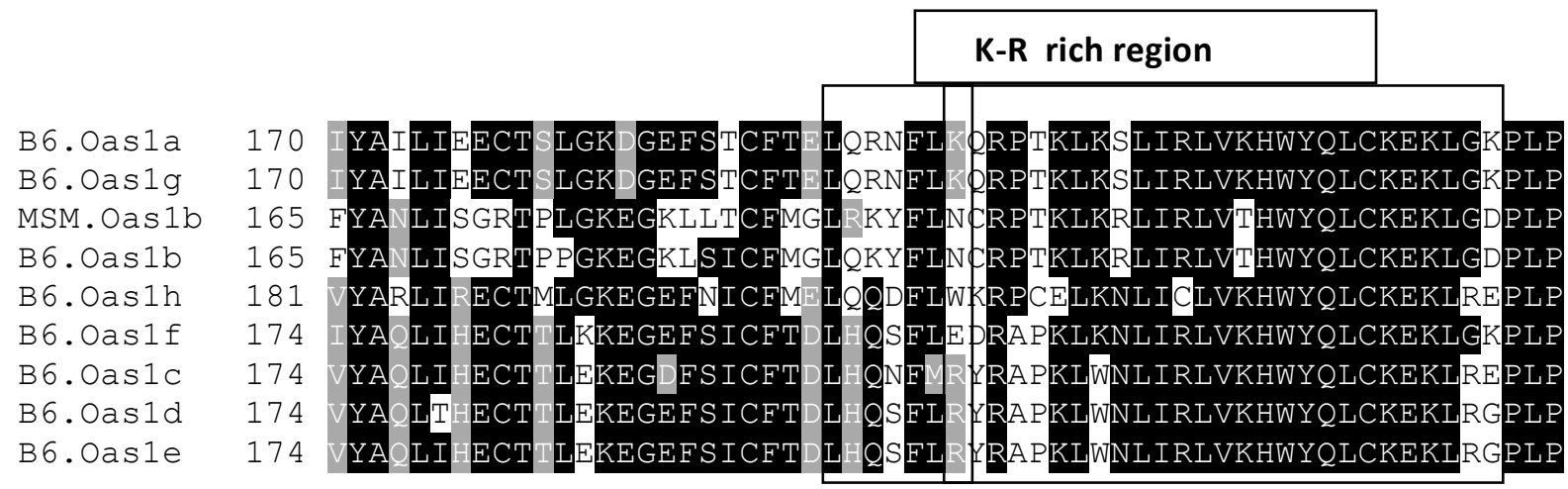


B6. Oasla B6. Oas1g MSM. Oas 1b B6.0as1b B6.Oas1h B6.0as1f B6. Oas1C B6. Oas1d B6.Oasle

B6. Oasla B6. Oaslg MSM. Oas1b B6.0as1b B6. Oas1h B6.0aslf B6. Oas1C B6. Oas1d B6.Oasle

B6. Oasla B6. Oaslg MSM. Oas1b B6. Oas1b B6. Oas1h B6.0aslf B6.0as1C B6. Oas1d B6.Oasle
230 230 225

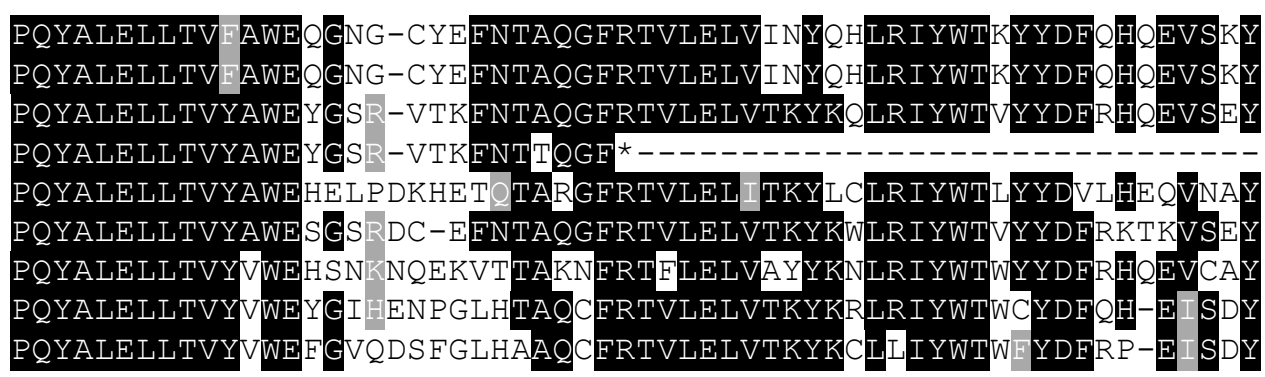

\section{CFK}

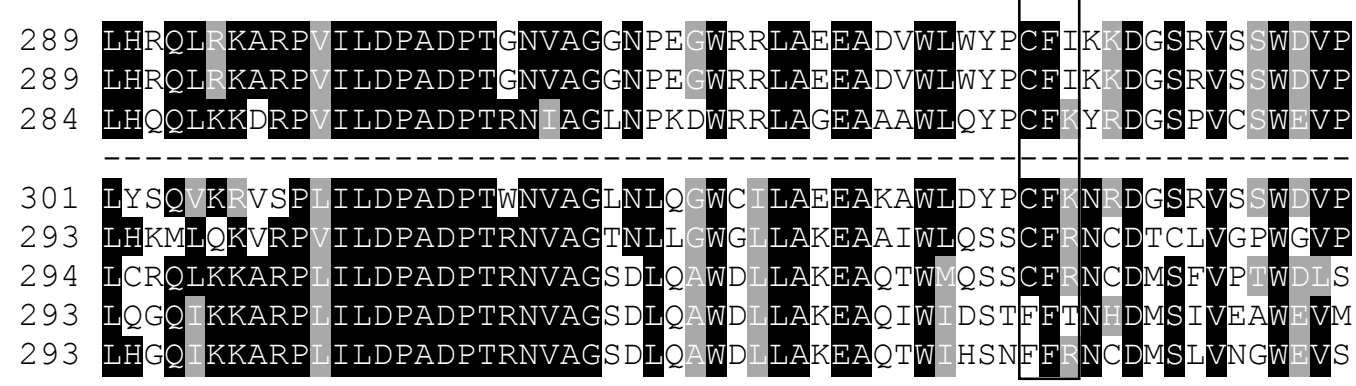

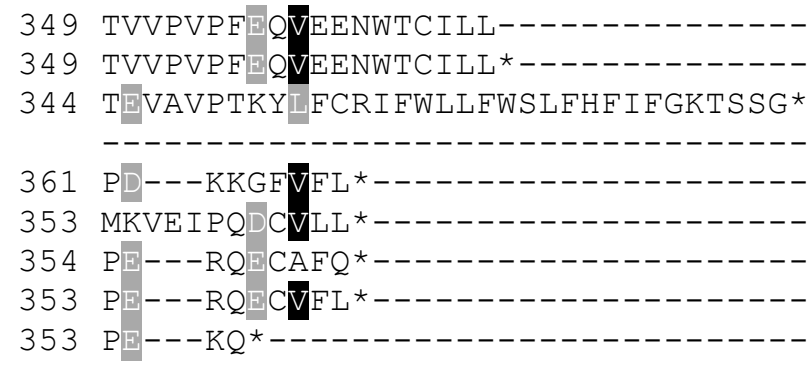


(B)

\begin{tabular}{|c|c|c|c|c|c|c|}
\hline Protein & LXXXP & P-Loop & D-box & $\begin{array}{c}\text { K- } \mathbf{R} \\
\text { Rich region }\end{array}$ & CFK & A.A \\
\hline Oas1a & LRSIP & KGGSSGKG & DAD & $\mathbf{K}$ & CFI & 368 \\
\hline Oas1b & \begin{tabular}{|l|} 
LRSIP \\
\end{tabular} & KG-KG & DAD & $\mathbf{N}$ & - & 253 \\
\hline MSM.Oas1b & \begin{tabular}{|l|} 
LRSIP \\
\end{tabular} & KG-KG & DAD & $\mathbf{N}$ & CFK & 376 \\
\hline Oas1c & LCSIQ & MGGSYDEH & EAK & $\mathbf{R}$ & CFR & 362 \\
\hline Oas1d & LFRTP & MGGCYNEY & EAK & $\mathbf{R}$ & FFT & 361 \\
\hline Oas1e & LFITP & MGGSYDEH & EAK & $\mathbf{R}$ & FFR & 356 \\
\hline Oas1f & LSSTP & MGGSYDEH & EAK & $\mathbf{E}$ & CFR & 364 \\
\hline Oas1g & LRSIP & KGGSSGKG & DAD & $\mathbf{K}$ & CFI & 367 \\
\hline Oas1h & LCSTP & MGGSNYRY & EVD & $\mathbf{w}$ & CFK & 369 \\
\hline
\end{tabular}

Figure 5. (A) Alignment of amino acid sequence in mouse Oas 1 paralogs. Amino acid sequence motifs important for the enzyme activity are shown in the box. Light gray rectangles, conserved OAS catalytic units; black rectangles, less conserved parts of the proteins. The multi-alignment was performed with the CLUSTALW program (www.ddbj.nig.ac.jp/E-mail/clustalw-j.html) using default parameters. The output was embellished using BOXSHADE 3.21 software (www.ch.embnet.org/software/ BOX_form.html). (B) Schematic diagram of mouse Oas1 protein and comparison of 5 motifs in mouse Oas 1 paralogs. 


\section{Summary}

The Interferon (IFN) has a critical role in host immune response and IFN is activated in response to viral infection. This study focused on the 2'-5' oligoadenylate synthetase (OAS) induced by IFN which plays an important role in innate antiviral response against viral infections.

To study the function of various isoform of OAS, the author investigated the expression of these genes in various organs in various ages of $\mathrm{C} 57 \mathrm{BL} / 6 \mathrm{~J}$ mice, new born ( 1 week old), young (5 weeks old), and adult ( 8 weeks old) and 5-week-old mice stimulated by poly I:C. The expression profile of the genes encoding OAS paralogs in different tissues indicates that the expression of Oas1a, Oas $1 b$, and Oas $1 g$ was much increased by the stimulation of poly I: $\mathrm{C}$ in all tissues. On the other hand, the Oas1c, Oas1d, and Oasle were expressed in ovary, and the Oas 1f was expressed in skin.

Next, the author evaluated the enzymatic activity of the B6-derived Oas1 paralogs in the HEK293FT cells. The result showed that Oas1a and Oas1g possessed the enzymatic activity, whereas Oas1b, Oas1c, Oas1d, Oas1e, Oas1f, Oas1h, and MSM-derived Oas1b did not possess the enzymatic activity. 


\section{Chapter II}

Antiviral Activities of Oas1 Paralogs 


\section{Introduction}

West Nile virus (WNV) and tick-born encephalitis virus (TBEV) belong to genus Flavivirus, family of Flavivirdea and both viruses are arthropod-borne and cause severe neurological diseases with extensive morbidity and mortality. In both viruses, the human is dead end host $(3,38,39)$. WNV is maintained in enzootic cycle between mosquitoes and birds. WNV also infects humans and other vertebrates and causes serious disease and death. Birds are one of the most important hosts in terms of the enzootic cycle, because they develop viremia. WNV infects mosquitoes, humans and horses, which are considered as incidental hosts (3). Since its initial isolation in Uganda in 1937 through the present, WNV has become an important cause of human and animal disease worldwide (40). TBEV is classified as one species with three subtypes namely the European subtype, the Siberian subtype and the Far Eastern subtype. TBEV is transmitted to humans through the bite of an infected tick of the Ixodes species, primarily I. ricinus (European subtype) or I. persulcatus (Siberian and Far Eastern subtypes) (30). The incidence of TBEV is increasing in many endemic areas in the European countries, Russia, and Far-Eastern Asia including Japan, and about 10,000 cases of the disease are reported every year. The Far-Eastern subtype of TBEV contains two strains, Safojin-HO strain, which is isolated in Japan and causes fatal infection to the nervous system, and Oshima strain, which is isolated from a dog in endemic area in Hokkaido, Japan in 1995 and identified as Russian spring-summer encephalitis. The author used in this study Oshima 5-10 strain, which infected mouse neurons and causes severe neurological signs and high mortality (14). Full length Oas1b has antiviral activity to Oshima 5-10 strain (34).

Recently many sub-genomic WNV and TBEV replicons that harbor a reporter gene instead of viral structural proteins, such as SEAP and luciferase reporter genes as shown in (Figures 6 and 7) have been reported and revealed their effectiveness for the evaluation of antiviral activities. Furthermore, this structure of replicon allows evaluation of the replication of virus in physical containment $\mathrm{P} 2$, and the replicons can replicate inside the cells without any cytopathic effect. 
Therefore, the replicons harboring reporter genes provide a fast and easy alternative for assessment of genome replication $(8,23,24,41)$. The most common reporter genes used for replicons are GFP, firefly luciferase and SEAP, and replicon can replicate easily with high efficiency of the amplification in BHK-21 cells with any cytopathic effect.

\section{WNV replicon}

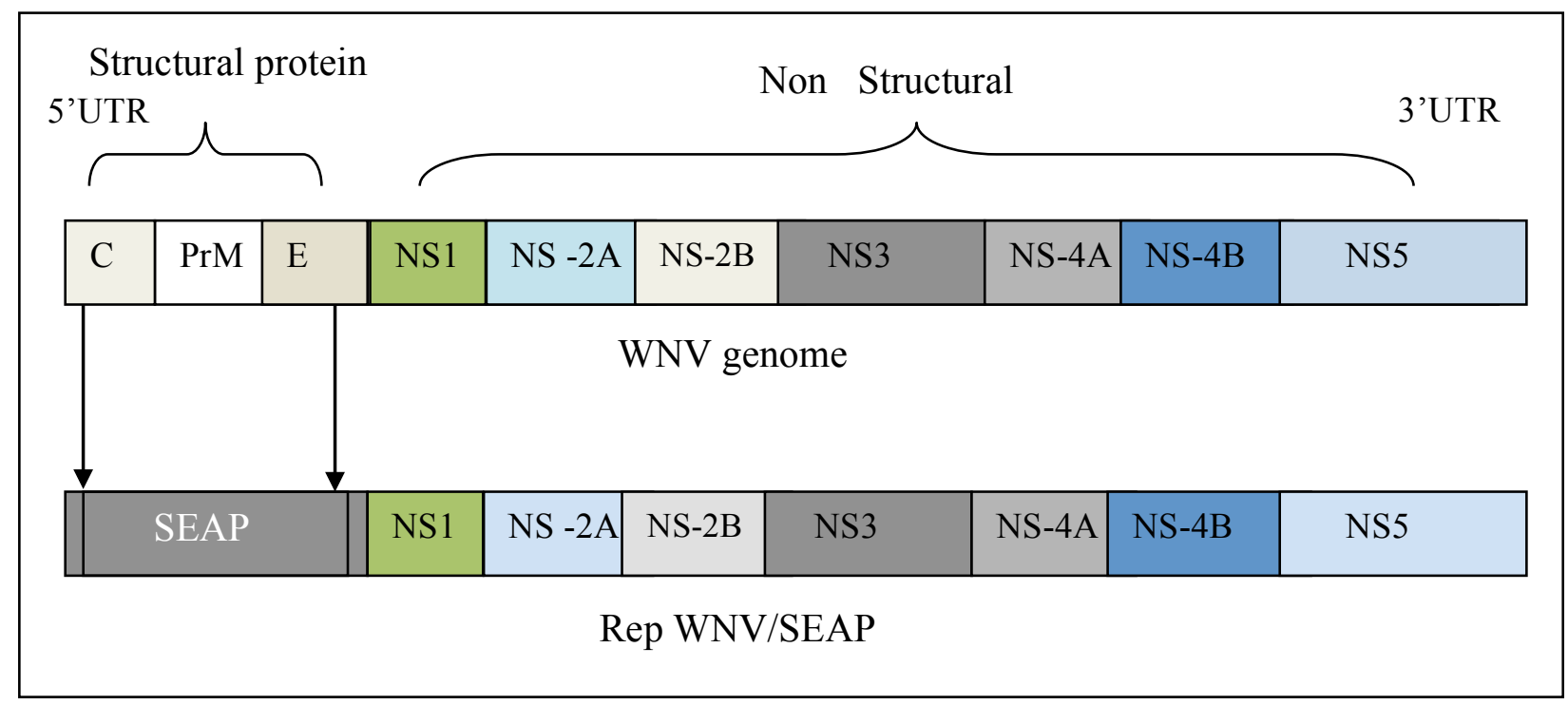

Figure 6. Schematic figure of repWNV/SEAP replicon. The SEAP reporter gene (black box) fused with the FMDV 2A sequence (gray box) is inserted upstream of the nonstructural (NS) coding region instead of viral structural protein, core (C), premembrane (prM) and envelope proteins (E). (Modified from Ref. 28) 


\section{TBEV replicon}

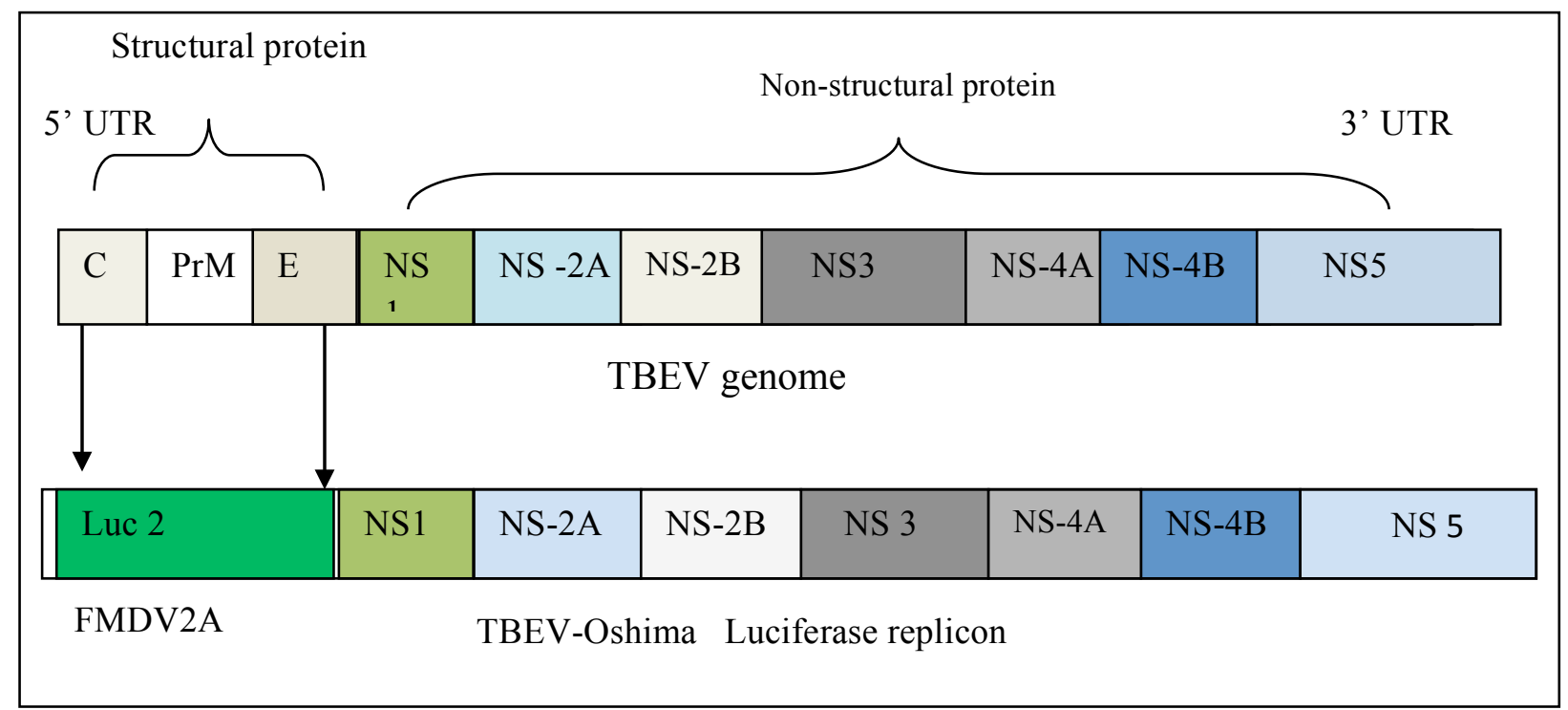

Figure 7. Schematic figure of the TBEV genome and replicon constructs. The gene for luciferase was inserted between the $\mathrm{C}$ and $\mathrm{E}$ protein-encoding regions of the TBEV genome. The foot and mouse disease virus (FMDV) 2A coding sequence (2A) was inserted between the C-terminus of luciferase gene and the NS1 signal sequence (modified from Ref. 34). 


\section{Material and Methods}

\subsection{Evaluation of the antiviral activity to WNV replicon}

BHK-21 cells were grown in DMEM (Gibco/Invitrogen) supplemented with $10 \%$ fetal bovine serum and $1 \%$ penicillin/streptomycin/Glutamine (Gibco/Invitrogen) at $37{ }^{\circ} \mathrm{C}$, and passaged at every two days. One day before transfection, cells were harvested, counted, and cultured in a 100$\mathrm{mm}$ dish at the cell density of $1.5 \times 10^{6}$ cells/dish for $24 \mathrm{hr}$. After the culture, the cells were transfected with $10 \mu \mathrm{g}$ of each plasmid, pB6.Oas1a-FL-EGFP, pB6.Oas1b-FL-EGFP, pB6.Oas1cFL-EGFP, pB6.Oas1d-FL-EGFP, pB6.Oas1e-FL-EGFP, pB6.Oas1f-FL-EGFP, pB6.Oas1g-FLEGFP, pB6.Oas1h-FL-EGFP as well as pMSM.Oas1b-FL-EGFP by using Lipofectamine ${ }^{\circledR} 2000$ (Gibco/Invitrogen, Carlsbad, CA, USA). After $24 \mathrm{hr}$ culture, the transfection efficiency was monitored by observation of EGFP expression and cells were transfected with $5 \mu \mathrm{g}$ of WNV replicon RNA conjugated with secreted alkaline phosphatase RNA (repWNV/SEAP) (19) by electoporation using a Gene Pulser Xcell (BioRad, Hercules, CA, USA) with two pulses of $1.5 \mathrm{kV}$ at $25 \mu \mathrm{F}$ and infinite resistance. After culturing cells for the indicated time, the SEAP activity in the culture medium was measured using a GreatEscAPe SEAP Chemiluminescence Kit 2.0 (ClontechBio. Inc). In order to assure the expression of transfected Oas1 paralogs, Western blot analysis with anti-FLAG antibody was performed at $72 \mathrm{hr}$ after transfection.

\subsection{Evaluation of antiviral activity to TBEV replicon}

BHK-21 cells were grown in the same conditions as shown above for the antiviral activity to WNV replicon. One day before transfection, cells were harvested, counted, and cultured in a 24well plate at the cell density of $1 \times 10^{5}$ cells/well. After $24 \mathrm{hr}$ culture, the cells were transfected with $1 \mu \mathrm{g}$ of each plasmid, pB6.Oas1a-FL-EGFP, pB6.Oas1b-FL-EGFP, pB6.Oas1cFL-EGFP, pB6.Oas1d-FL-EGFP, pB6.Oas1e-FL-EGFP, pB6.Oas1f-FL-EGFP, pB6.Oas1g-FL- 
EGFP, pB6.Oas1h-FL-EGFP as well as pMSM.Oas1b-FL-EGFP by using Lipofectamine ${ }^{\circledR} 2000$. After $24 \mathrm{hr}$ culture, cells were transfected with $700 \mathrm{ng} /$ well of TBEV-Oshima replicon harbouring the luciferase reporter gene (33) by Lipofectamine ${ }^{\circledR}$ 2000. After culturing for the indicated time, luciferase activities were determined using a Luciferase Assay System (Promega, Madison, WI, USA) according to the manufacturer's instructions. For the assay of the luciferase activity, the cells were washed once with PBS, lysed with $100 \mu 1$ of the cell lysis buffer in the kit, $20 \mu 1$ of luciferase substrate solution in the kit was added to each well, and the luciferase activity was measured by an AB-2100 Light Luminescencer JNR (ATTO, Tokyo, Japan).

\subsection{Statistical analysis}

All experiments were performed three times independently. Data were subjected to the one-way analysis of variance (ANOVA) using SPSS 16.0 software. All values were represented as means \pm SD. Statistical differences were analysed using Tukey HSD test. Values of $p<0.05$ and $p<0.01$ were considered to be significant. 


\section{Results}

\subsection{The antiviral activity of the mouse Oas1 family against WNV replicon}

To analyze the antiviral activity, a repWNV/SEAP replicon was used, in which the SEAP reporter gene was harbored instead of viral structural protein so that the replication of viral genome could be easily determined in the culture media as secreted SEAP activity as shown in (Fig.6). BHK-21 cells were transfected with each Oas 1 gene paralog, repWNV/SEAP replicon was transfected by electroporation after $24 \mathrm{hr}$, and then SEAP activity in the culture medium was assayed after culturing for $72 \mathrm{hr}$ (Figure. 8"(A)"). The result indicates that MSM-derived Oas1b showed highly significant $(p<0.01)$ inhibition against WNV-replicon replication in comparison with the pIRES-EGFP (Figure. 8"(A)"). In respect of B6-derived Oas1a, Oas1c, Oas1e, Oas1f, and Oas1g, all of them showed the similar SEAP activity level to that of pIRES-EGFP transfected cells. On the other hand, B6-derived Oas1b and Oas1h $(p<0.05)$ as well as Oas1d $(p<0.01)$ showed statistically significant inhibition, when compared with the pIRES-GFP (Figure. 8"(A)"). To verify no change in the expression level of each paralog gene during culture, I compared expression level of each paralogs gene in the cell before electroporation of WNV-replicon with the expression level after the SEAP assay. As shown in (Figure. 8"(B)", the expression level of all genes was not different in the cell between before electroporation of WNV-replicon and after SEAP assay. Furthermore, I confirmed expression level of each paralog protein by Western blot analysis at $72 \mathrm{hr}$ after transfection. As shown in (Figure. 8. "(C)"), expression of proteins was also similar level among all transfected paralogs at $72 \mathrm{hr}$ after the transfection. These results indicate that only MSMderived Oas $1 \mathrm{~b}$ possesses strong anti-flavivirus activity and B6-derived Oas1b, Oas1d, and Oas1h possess weak but significant anti-flavivirus activity. 
(A)

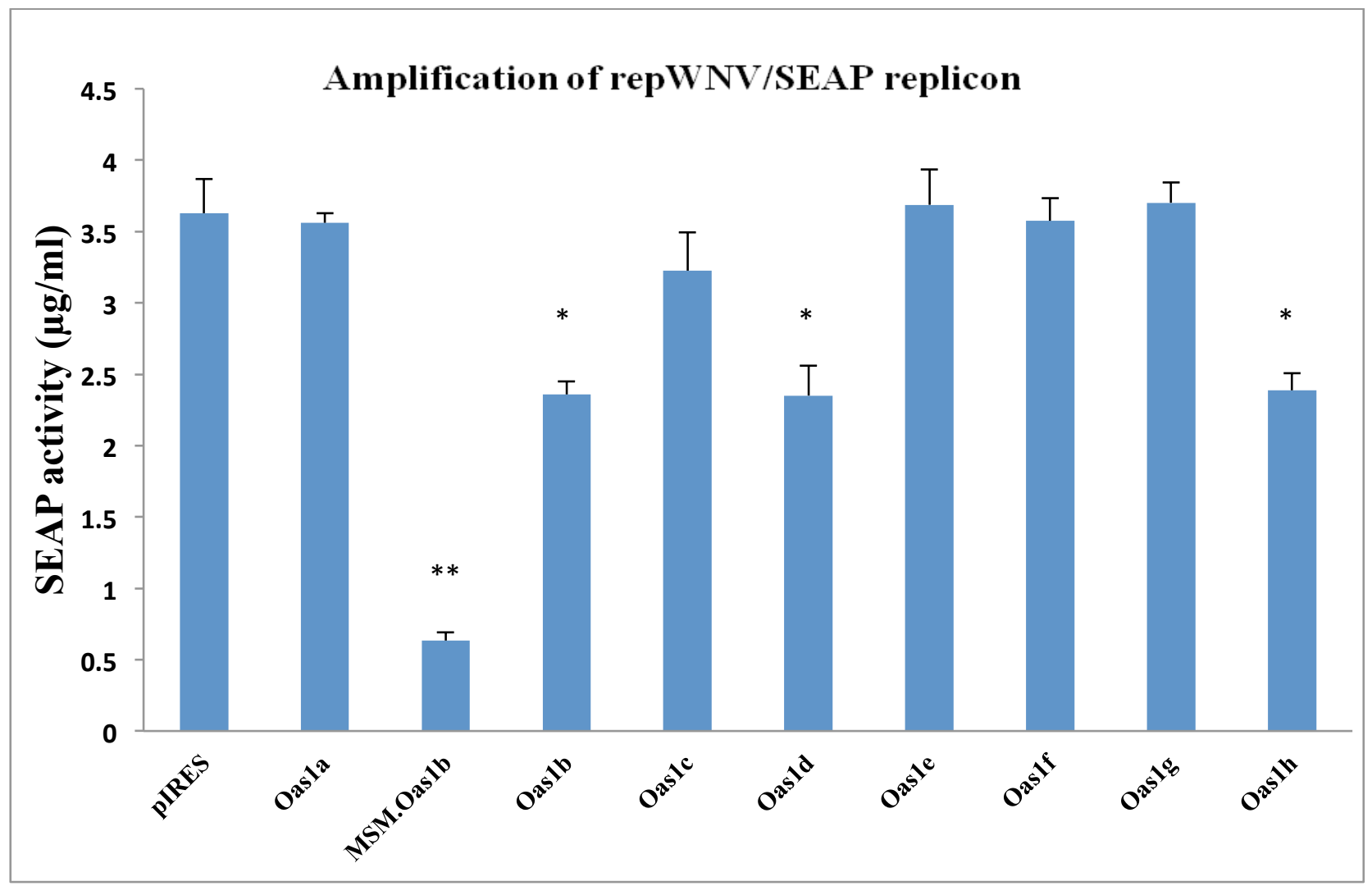

(B)

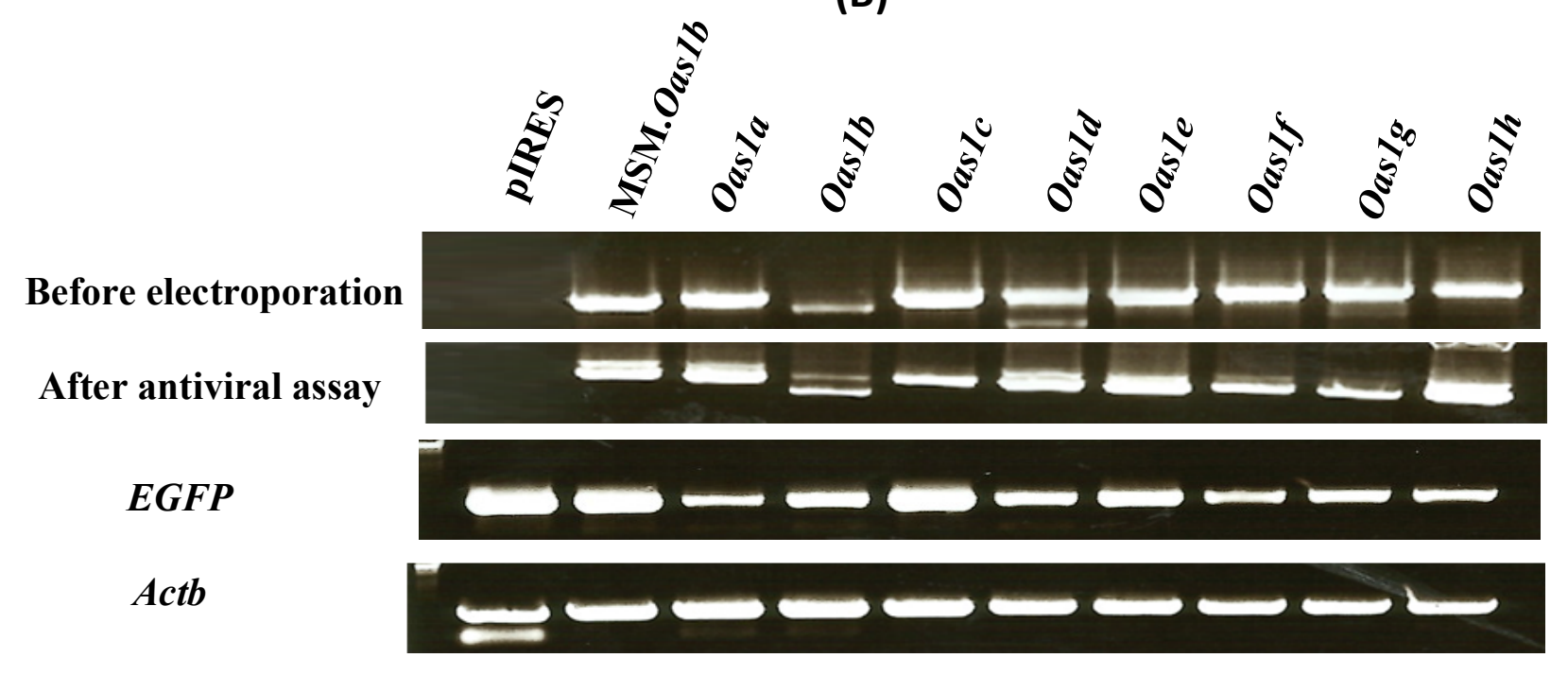




\section{(C)}

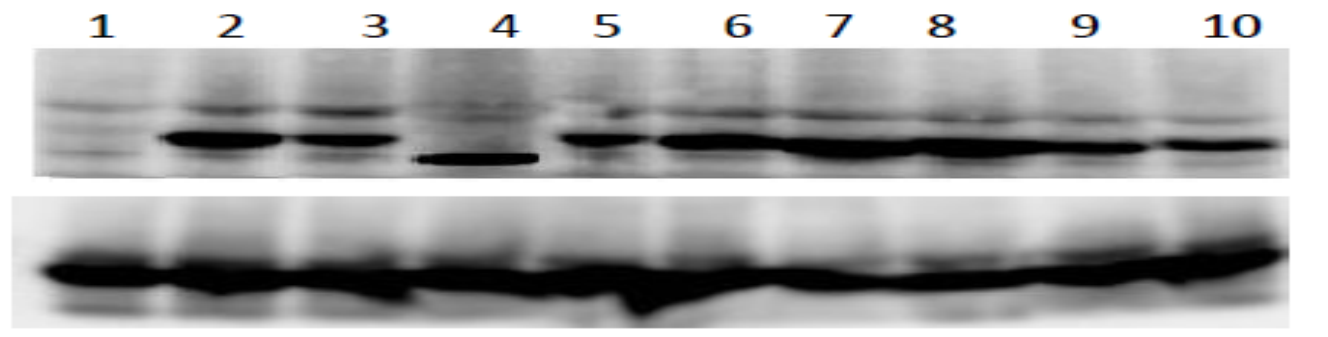

Actb

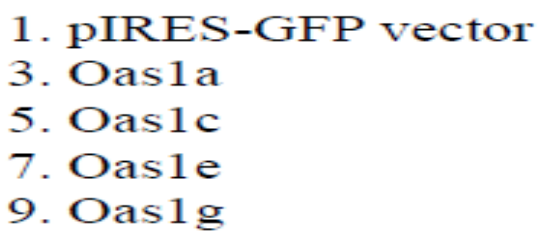

1. pIRES-GFP vector

3. Oas 1 a

7. Oasie

9. Oas1g
2. MSM.Oas $1 b$
4. Oas $1 b$
6. Oas $1 \mathrm{~d}$
8. Oas $1 \mathrm{f}$
10. Oas $1 \mathrm{~h}$

Figure 8. (A) Antiviral activity of the mouse Oas1 paralogs expressed in the BHK-21 cells against WNV replicon. The BHK-21 cells were transfected with each mouse Oas 1 paralog gene, the number of EGFP-positive cells was counted at $24 \mathrm{hr}$ after the transfection, and SEAP activity was measured in the supernatant at $72 \mathrm{hr}$ after the electroporation of repWNV/SEAP replicon. The data are normalized as follows; raw SEAP activity data are divided by the ratio of EGFPpositive cells so that the SEAP activity is expressed as the value that all cells are assumed to express transfected paralog genes. The data are expressed as the mean $\pm \mathrm{SD}(\mathrm{n}=3)$. **, $P<0.01$ vs vector only (pIRES);,$P<0.05$ vs vector only (pIRES). (B) Confirmation of the expression level of the mouse Oas1 paralog genes in the BHK-21 cells by RT-PCR before the electoporation of repWNV/SEAP replicon and after the antiviral assay. There was no significant difference in the expression level of transfected genes between before the electoporation of the replicon and after the antiviral assay. (C) Homogenates of BHK-21 cells transfected each Oas1 paralog at $72 \mathrm{hr}$ after transfection were subjected to Western blot analysis using anti-FLAG antibody to assure retaining of the proteins transfected genes. All paralog proteins were retained in the cell with the similar extent. 


\subsection{The antiviral activity of the mouse Oas1 family against TBEV replicon}

To confirm the above results, the author analyzed anti-flavivirus activity using different flavivirus replicon, the TBEV-Oshima 5-10 replicon. This replicon harbors the luciferase reporter gene instead of the structural protein-coding genes (33). As shown in (Figure 7), MSM-derived Oas1b only showed highly significant $(p<0.01)$ inhibition in the TBEV-replicon replication in comparison with the pIRES-EGFP. Regarding the B6-derived Oas1 paralogs, all paralogs did not show antiviral activity toward the TBEV-replicon in comparison with the pIRES-EGFP (Figure 9). These results together with the results using repWNV/SEAP replicon suggest that only MSMderived Oas1b possess overt anti-flavivirus activity, whereas other all Oas1 paralogs including B6derived Oas $1 \mathrm{~b}$ do not possess anti-flavivirus activity, although B6-derived Oas1b, Oas1d, and Oas1h might possess potential for weak anti-flavivirus activity, which is possibly depending on the virus species. 


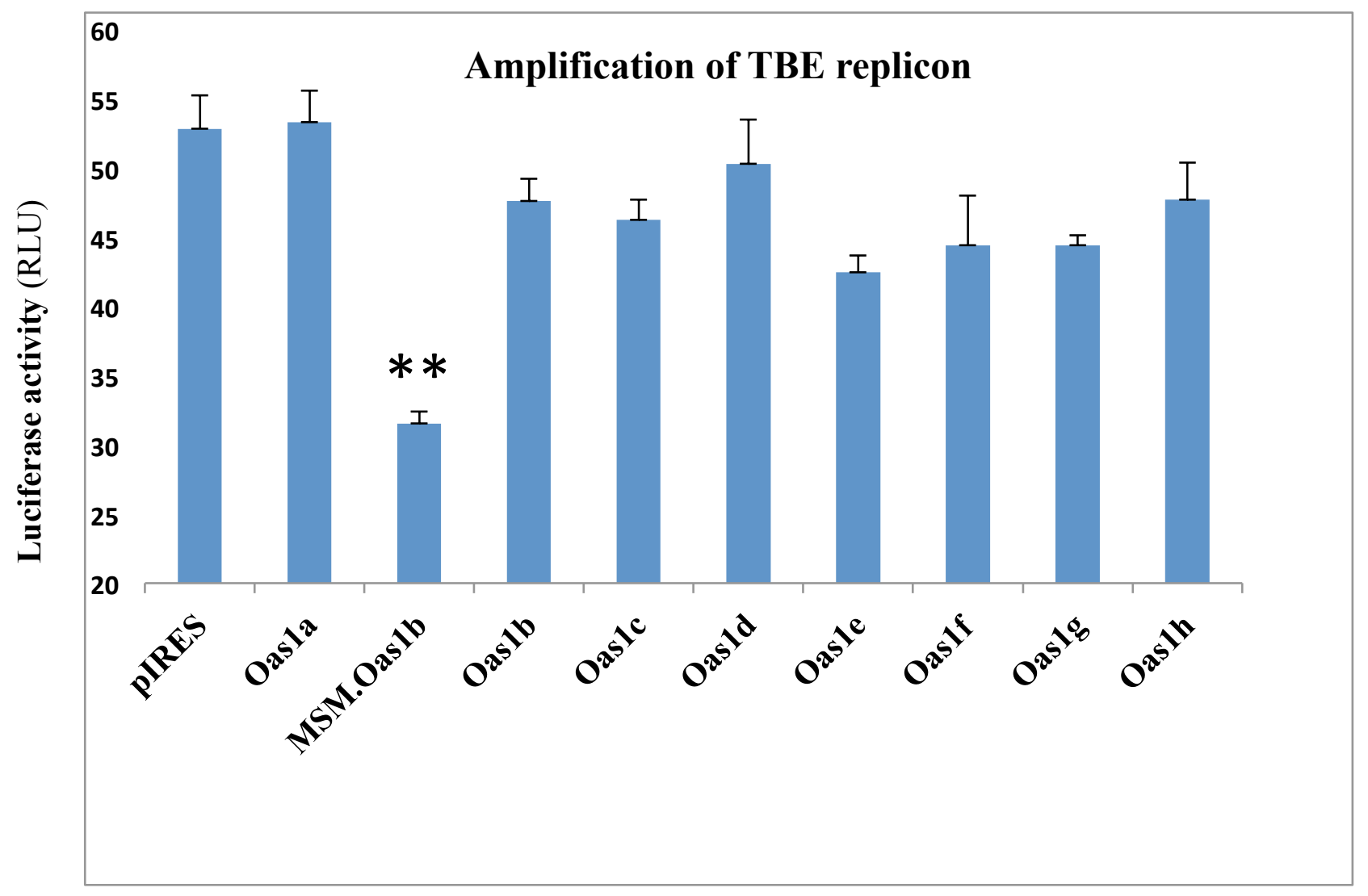

Figure 9. Antiviral activity of the mouse Oas1 paralogs expressed in the BHK-21 cells against TBEV replicon. The BHK-21 cells were transfected with each mouse Oas1 paralogs gene, the number of EGFP-positive cells was counted at $24 \mathrm{hr}$ after the transfection, and luciferase activity was measured in the homogenates at $48 \mathrm{hr}$ after the transfection of TBEV-Oshima replicon. The data are normalized as follows; raw luciferase activity data are divided by the ratio of EGFP-positive cells so that the luciferase activity is expressed as the value that all cells are assumed to express transfected genes. The data are expressed as the mean $\pm \mathrm{SD}(\mathrm{n}=2){ }^{* *}, P<0.01$ vs vector only (pIRES). 


\section{Discussion}

The positional cloning strategy identified feral mouse-derived Oas $1 \mathrm{~b}$ as a resistant factor to the flavivirus infection $(21,26)$, and as a potent inhibitor of WNV and TBEV-Oshima strain replication by preventing the viral RNA accumulation in the infected cells $(14,43)$. A nonsense mutation of B6-derived Oas1b is the main cause of susceptibility to the flavivirus infection in all laboratory mice $(21,26)$. Knocking-in the functional Oas $1 b$ from resistant strain into susceptible laboratory mouse strain altered phenotype resistant to the flavivirus infection (34). Recently, the congenic mouse B6.MSM-Oas possessing the functional Oas $1 b$ was developed as a good model to study the flavivirus infection. B6.MSM-Oas congenic mice showed resistance to WNV and TBEV but not to other virus infection such as influenza virus and Sendai virus (24, 42 and unpublished data). Therefore, the author evaluated the antiviral activity of Oas 1 paralogs to WNV and TBEV-Oshima strain. The author used BHK-21 cells, because the replicon can easily replicate in this cell line without any cytopathic effects. The results showed that the MSM-derived Oas1b possessed a significant antiviral activity in comparison with other B6-derived Oas1 paralogs for WNV replicon. The B6-derived Oas1b, a truncated protein, Oas1d, and Oas1h also showed antiviral activity against the WNV replicon, although antiviral activities of these paralogs were less than that of MSMderived Oas $1 \mathrm{~b}$. To confirm that the B6-derived Oas1b, Oas1d, and Oas $1 \mathrm{~h}$ surely possess antiflavivirus activity, the author performed measurement of the anti-flavivirus activity of them using other flavivirus replicon, a TBEV-Oshima replicon. For TBEV-Oshima replicon, MSM-derived Oas1b also possessed a significant antiviral activity; however, the B6-derived Oas1b, Oas1d, and Oas1h did not show any significant antiviral activity against the TBEV as well as other all paralogs. Taken together the results of antiviral activities using the two different flavivirus replicons, the author concludes that the MSM-derived Oas1b definitely possesses antiviral activity, whereas although B6-derived Oas1b, Oas1d, and Oas1h may possess the potential to antiviral activity, this activity is limited depending on the species of flavivirus. This conclusion is consistent with the 
result of the in vivo infection experiment that the MSM but not the B6 mouse is resistant to the flavivirus infection including WNV and TBEV. 


\section{Summary}

The author evaluated the antiviral activity of mouse Oas1 paralogs against two major neurotropic flaviviruses, WNV and TBEV, by using repWNV/SEAP, which was harboured SEAP reporter gene, and Oshima 5-10 replicon, which was harboured luciferase reporter gene. For WNV replicon, MSM-derived Oas1b possessed a significant antiviral activity. In addition, B6-derived Oas1b, a truncated protein, Oas1d, and Oas1h also showed antiviral activity against the WNV replicon, although antiviral activities of these paralogs were less than that of MSM-derived Oas1b. For TBEV Oshima 5-10 replicon, only MSM-derived Oas1b possessed a significant antiviral activity; however, other Oas1 paralogs did not show any significant antiviral activity against the TBEV. 


\section{Conclusion}

In this study, the author concludes that mouse Oas 1 family has different tissue expression pattern; the expression of Oasla, Oas 1 , and Oas $1 g$ was ubiquitous and dependent on poly I:C stimulation, whereas expression of other Oas1 paralogs were all tissue-specific and relatively independent of poly I:C stimulation. These results suggest that the Oas1a, Oas1b, and Oas 1g play a role in the protection from the virus infection, whereas other Oas1 paralogs play a role in tissuespecific functions. Furthermore, the Oas1a and Oas1g were enzymatically active, whereas the Oas1b, Oas1c, Oas1d, Oas1e, Oas1f, and Oas1h were enzymatically inactive. Although B6-derived Oas1b, Oas1d, and Oas1h showed weak antiviral activity against the WNV replicon, only feral mouse MSM-derived Oas1b possessed significant antiviral activity against both WNV and TBEV. Moreover, it was independent of the OAS enzymatic activity. From these results, it is suggested that the Oas1a and Oas1g play a role in potentiating IFN signals via produced 2-5A, RNase L, and pattern recognition receptors such as RIG-I and MDA5 pathway, whereas Oas $1 \mathrm{~b}$, if it is full length, plays a role in inhibiting replication of flaviviruses specifically. Rests of other Oas 1 paralogs were not drastically induced by IFN and suggested to play a role in tissue-specific and not yet fully known functions. The genomic structure of the rat Oas is similar to that of mouse, possessing multiple paralogs of Oas1 as well as the mouse (27). In contrast, other mammals such as human possess only one gene of OAS1. Human OAS1 possesses both enzymatic and anti-flavivirus activities, suggesting that human OAS1 possesses the combined functions that mouse Oas1a, Oas1g, and Oas1b possess. Such evolutional difference is very interesting; however, the reason for the difference is unknown and should be elucidated by further investigations. 


\section{Acknowledgment}

In the name of Allah, most gracious, most merciful First of all, I thank Almighty of Allah to give me the ability to finish this study and get some valuable results. Also, I would like to extend my deeply gratitude to my supervisor of this study, Prof. Takashi Agui, Laboratory of Laboratory Animal Science and Medicine, Department of Disease Control, Graduate School of Veterinary Medicine, Hokkaido University for his help and guidance valuable for my studies and this project. I also would like to mention that the kindness and respect I have received from Prof. Takashi Agui have provided me the power to face any problem that I experienced each day. Furthermore, I would like to thank Prof. Masami Morimatsu, Dr. Hassan T. Tag-El-Din-Hassan and all my laboratory members for their advices and recommendations to revise this dissertation. I also would like to thank Dr. Yoshii, Laboratory of Public Health, Graduate School of Veterinary Medicine, Hokkaido University for TBEV-Oshima replicon. I would like to thank Prof. Ohashi, Laboratory of Infectious Diseases and Prof. Sakoda, Laboratory of Microbiology, Graduate School of Veterinary Medicine, Hokkaido University, for reviewing my thesis. Finally, I want to dedicate this work to my new born san Mazen and my daughter Rewan, my parents and all my family especially my husband, Sabry Abd Allah, who supported me by all possible means to complete my studies. 


\section{References}

1. Castelli, J. C., Hassel, B. A., Maran, A., Paranjape, J., Hewitt, J. A., Li, X-L., Hsu, Y-T., Silverman, R. H. and Youle, R. J. 1998. The role of 2'-5' oligoadenylate-activated ribonuclease L in apoptosis. J. Cell Death Differentiat. 5: 313-320.

2. Chakrabarti, A., Jha, B. K.and Silverman, R. H. 2011. New insights into the role of RNase L in innate immunity. J. Interferon Cytokine Res. 31: 49-57.

3. Chancey, C., Griney, A., Volkova, E. and Rios, M. 2014. The global ecology and epidemiology of West Nile virus. Bio. Med. Res. Int. 2015: 1-20.

4. Eskildsen, S., Hartmann, R., Kjeldgaard, N. O. and Justesen, J. 2002. Gene structure of the murine 2'-5'-oligoadenylate synthetase family. Cell. Mol. Life Sci. 59: 1212-1222.

5. Elbahesh, H., Jha, B.K., Silverman, R. H., Scherbik, S.V. and Brinton, M. A. 2011. The Flv ${ }^{r}$ encoded murine oligoadenylate synthetase $1 \mathrm{~b}$ (Oas $1 \mathrm{~b})$ suppresses 2-5A synthesis in intact cells. J. Virol. 409: 262-270.

6. Ghosh, A., Sarkar, S. N., Guo, W., Bandyopadhyay, S. and Sen , G. C. 1997. Enzymatic activity of $2^{\prime}-5^{\prime}$-oligoadenylate synthetase is impaired by specific mutations that affect oligomerization of the protein. J. Biol. Chem. 272: 33220-33226.

7. Hartmann, R., Justesen, J., Sarkar, S. N., Sen G. C. and Yee, V. C. 2003. Crystal structure of the 2'-specific and double-stranded RNA-activated interferon-induced antiviral protein 2'-5'oligoadenylate synthetase. Mol. Cell 19: 1173-1185.

8. Hayasaka, D., Yoshii, K., Ueki,T., Iwasaki,T. and Takashima, I. 2004. Sub-genomic replicons of Tick-borne encephalitis virus. Arch. Virol. 149: 1245-1256.

9. Hirano, M., Yoshii, K., Sakai, M., Hasebe, R., Ichii, O. and Kariwa H. 2014. Tick-borne flaviviruses alter membrane structure and replicate in dendrites of primary mouse neuronal cultures. J. Gen. Virol. 95: 849-861. 
10. Hovanessian, A. G. and Justesen, J. 2007. The human 2'-5' oligoadenylate synthetase family: unique interferon-inducible enzymes catalyzing 2'-5' instead of 3'-5' phosphodiester bond formation. Biochimie 89: 779-788.

11. Hovnanian, A., Rebouillat, D., Mattei, M. G., Levy, E. R., Marié, I., Monaco, A. P., and Hovanessian, A. G. 1998. The human 2', 5'-oligoadenylate synthetase locus is composed of three distinct genes clustered on chromosome 12q24.2 encoding the 100-, 69-, and 40kDa forms. Genomics 52: 267-277.

12. Kristiansen, H., Gad, H. H., Eskildsen-Larsen, S., Despres, P. and R. Hartmann. 2011. The oligoadenylate synthetase family: An ancient protein family with multiple antiviral activities. J. Interferon Cytokine Res. 31: 41-47.

13. Kakuta, S., Shibata, S. and Iwakur, Y. 2002. Genomic structure of the mouse $2^{\prime}-5^{\prime}-$ oligoadenylate synthetase gene family. J. Interferon Cytokine Res. 22: 981-993.

14. Kajaste-Rudnitski, A., Mashimo, T., Frenkiel, M. P., Guénet, J. L., Lucas, M. and Desprès, P. 2006. The 2',5'-oligoadenylate synthetase $1 \mathrm{~b}$ is a potent inhibitor of West Nile virus replication inside infected cells. J. Biol. Chem. 281: 4624-4637.

15. Lopp, A., Kuusksalu, A, Reintamm, T., Müller, W. E. and Kelve, M. 2002. 2,5-oligoadenylate synthetase from a lower invertebrate, the marine sponge Geodia cydonium, does not need dsRNA for its enzymatic activity. Biochim. Biophys. Acta 1590: 140-149.

16. Mandal, S., Abebe, F. and Chaudhary, J. 2011. 2'-5'oligoadenylate synthetase 1 polymorphism is associated with prostate cancer. Cancer 117: 5509-5518.

17. Mansfield, K. L., Johnson, N., Phipps, L. P., Stephenson, J. R., Fooks, A. R. and Solomon, T. 2009. Tick-borne encephalitis virus - a review of an emerging zoonosis. J. Gen Virol. 90:1781-1794.

18. Malathi, K., Paranjape, J. M., Bulanova, E., Shim, M., Guenther-Johnson, J. M., Faber, P. W., Eling, T. E., Williams, B. R. and Silverman R. H. 2005. A transcriptional signaling 
pathway in the IFN system mediated by 2'-5'-oligoadenylate activation of RNase L. Proc. Nat. Acad. Sci. USA. 102: 14533-14538.

19. Malathi, K., Dong, B., Gale, M. J. and Silverman, R. H. 2007. Small self-RNA generated by RNase L amplifies antiviral innate immunity. Nature 448: 816-819.

20. Mashimo, T., Glaser, P., Lucas, M., Simon-Chazottes, D., Ceccaldi, P. E., Montagutelli, X. Desprès, P. and Guénet, J. L. 2003. Structural and functional genomics and evolutionary relationships in the cluster of genes encoding murine 2,5-oligoadenylate synthetase. Genomics 82:537-552.

21. Mashimo, T., Lucas, M., Simon-Chazottes, D., Frenkiel, M. P., Montagutelli, X., Ceccaldi, P. E., Deubel, V., Guénet, J. L. and Despres, P. 2002. A nonsense mutation in the gene encoding $2^{\prime}-5^{\prime}$-oligoadenylate synthetase/L1 isoform is associated with West Nile virus susceptibility in laboratory mice. Proc. Natl. Acad. Sci. USA. 99: 11311-11316.

22. Marie, I., Blanco, J., Rebouillat, D., and Hovanessian, A. G. 1997. 69-kDa and 100-kDa isoforms of interferon-induced 2 -5 oligoadenylate synthetase exhibit differential catalyticparameters. Eur. J. Biochem. 24: 8558-8566.

23. Maeda, J., Takagi, H., Hashimoto, S., Kurane,I., and Maeda. A. 2008. A PCR-based protocol for generating West Nile virus replicons. J. Virol. Meth. 148: 244-252.

24. Moritoh, K., Maeda, A., Nishino, T., Sasaki, N. and Agui, T. 2011. Development and application of West Nile virus sub genomic replicon RNA expressing secreted alkaline phosphatase. J. Vet. Med. Sci. 73: 683-686.

25. Moritoh, K., Yamauchi, H., Asano, A., Yoshii, K., Kariwa, H., Takashima, I., Isoda, N., Sakoda, Y., Kida, H., Sasaki, N. and Agui, T. 2009. Generation of congenic mouse strains by introducing the virus-resistant genes, $\mathrm{Mx} 1$ and Oas1b, of feral mouse-derived inbred strain MSM/Ms into the common strain C57BL/6J. Jpn. J. Vet. Res. 57: 89-99. 
26. Perelygin, A. A., Scherbik, S. V., Zhulin, I. B., Stockman, B. M., Li, Y. and Brinton, M. A. 2002. Positional cloning of the murine flavivirus resistance gene. Proc. Natl. Acad. Sci. USA. 99: 9322-9327.

27. Perelygin, A. A., Zharkikh, A. A., Scherbik, S. and Brinton, M. A. 2006. The mammalian 2'-5' oligoadenylate synthetase gene family: evidence for concerted evolution of paralogous Oas1 genes in Rodentia and Artiodactyla. J. Mol. Evol. 63: 562-576.

28. Pfeffer, M., and Dobler, G. 2010. Emergence of zoonotic arboviruses by animal trade and migration. Parasites Vectors 3: 1-15.

29. Pradier, S., Lecollinet, S. and Leblond, A. 2012. West Nile virus epidemiology and factors triggering change in its distribution in Europe. Rev Sci Tech. 3: 829-44.

30. Rebouillat, D. and Hovanessian, A. G. 1999. The human 2', 5'-oligoadenylate synthetase family: interferon-induced proteins with unique enzymatic properties. J. Interferon Cytokine Res. 19: 295-308.

31. Rebouillat, D., Hovnanian, A., David, G., Hovanessian, A. G. and Williams, B. R. 2000. Characterization of the gene encoding the $100-\mathrm{kDa}$ form of human $2^{\prime}, 5^{\prime}$ oligoadenylate synthetase. Genomics 70: 232-240.

32. Sadler, A. J. and Williams, B. R. 2008. Interferon-inducible antiviral effectors. Nat. Rev. Immunol. 8:559-568.

33. Silverman, R. H. 2007. A scientific journey through the 2-5A/RNase L system. Cytokine Growth Factor Rev. 18: 381-388.

34. Scherbik, S. V., Kluetzman, K., Perelygin, A. A. and Brinton, M. A. 2007. Knock-in of the Oas $1 b^{r}$ allele into a flavivirus-induced disease susceptible mouse generates the resistant phenotype. J. Virol. 368: 232-237.

35. Saraste, M., Sibbald P. R. and Wittinghofer, A. 1990. The P-loop - a common motif ATP and GTP-binding proteins. Trends Biochem. Sci. 15: 430-434. 
36. Sawai, H., Ishibashi, K., Itoh. M. and Watanabe, S. 1985. Radioimmuno assay for 2-5 A using a novel 125I-labeled 2-5 A analog, and analysis of 2-5 A and 2-5 A synthetase activity in human plasma. Prog. Clin. Biol. Res. 202: 97-104.

37. Tag-El-Din-Hassan, H. T., Sasaki, N., Moritoh, K., Torigoe, D., Maeda, A. and Agui, T. 2012. The chicken 2'-5' oligoadenylate synthetase A inhibits the replication of West Nile virus. Jpn. J. Vet. Res. 60: 95-103.

38. Turtle, L., Griffiths, M. J. and Solomon, T. 2012. Encephalitis caused by flaviviruses. QJM. 105: 219-223.

39. Yan, W., Ma, L., Stein, P., Pangas, S. A., Burns, K. H., Bai, Y., Schultz, R. M. and Matzuk, M. M. 2005. Mice deficient in oocyte-specific oligoadenylate synthetase-like protein OAS1D display reduced fertility. J. Mol. Cell. Biol. 25: 4615-4624.

40. Yamamoto, Y., Sono, D. and Sokawa, Y. 2000. Effects of specific mutations in active site motifs of 2', 5'-oligoadenylate synthetase on enzymatic activity. J. Interferon Cytokine Res. 20: 337-344.

41.Yoshii, K., Ikawa, A., Chiba, Y., Omori, Y., Maeda, J., Murata, R., Kariwa, H. and Takashima, I. 2009. Establishment of a neutralization test involving reporter geneexpressing virus-like particles of tick-borne encephalitis virus. J. Virol. Meth. 161: 173-176.

42. Yoshii, K., Moritoh, K., Nagata, N., Yokozawa, K., Sakai, M., Sasaki, N., Kariwa, H., Agui, T. and Takashima, I. 2013. Susceptibility to flavivirus-specific antiviral response of Oas1b affects the neurovirulence of the Far-Eastern subtype of tick-borne encephalitis virus. Arch. Virol. 158: 1039-1046.

43. Zhou, A., Paranjape, J., Brown, T. L., Nie, H., Naik, S., Dong, B., Chang, A., Trapp, B., Fairchild, R., Colmenares, C. and Silverman, R. H. 1997. Interferon action and apoptosis are defective in mice devoid of 2-5-oligoadenylate-dependent RNase L. EMBO J. 16: 6355-6363. 


\section{Summary in Japanese}

本研究において、著者はマウスの Oas1 ファミリー遺伝子が異なる組織発現パターンを示すこと を明らかにした。即ち、Oasla、Oaslb 及び Oas 1 遺伝子の発現はあらゆる組織で見られ、ポリ I:C の刺激により増強したが、他の Oas1 パラログ遺伝子の発現は組織特異的で、ポリ I:C の刺激 により殆ど増強しなかった。これらの結果は Oas1a、Oas1b 及び Oas1g はウイルス感染の防御に働 き、他の Oas1 パラログは組織特異的に何らかの働きをしていることが示唆された。更に、Oas1a と Oas1g は OAS 酵素活性を有していたが、他の Oas パラログは全て酵素活性を有していなかった。 B6 マウス由来の Oas1b、Oas1d 及び Oas1h は WNV レプリコンに対し弱い抗ウイルス活性を有し ていたが、野生マウス、MSM 由来の Oas1bのみが WNV 及び TBEV 両レプリコンに対し唯一強い 抗ウイルス活性を有していた。更にこの抗ウイルス活性は酵素活性を必要としなかった。これら の結果より、Oas1a と Oas1g は OAS 酵素活性により産生された 2-5A、RNase L 及び RIG-I や MDA5 などのパターン認識受容体を介して IFN の効果を増強する働きをしているのに対し、Oas1b は全長にわたり欠損していない状態であればフラビウイルスの複製を特異的に阻害する働きをし ていることが示唆された。他の Oas1 パラログは IFNにより発現が増強しないことから、ウイルス 感染防御とは関係のない発現組織に特異的な、しかしながら未だ解明されていない何らかの機能 を有していると考えられた。ラットの Oas ゲノム構造もマウスのそれに類似し、マウスと同様複 数の Oas1 パラログ遺伝子を有していることが知られている。一方、ヒトを代表とする他のほ乳類 では $O A S 1$ 遺伝子は 1 種類のみである。ヒト OAS1 は酵素活性と抗フラビウイルス活性の両方を 有しており、マウスの Oas1a、Oas1b 及び Oas1g の機能を併せ持った状態である。このような進化 的相違は大変興味深いが、その理由は解明されておらず、更なる研究が必要である。 